-1 :
I b S

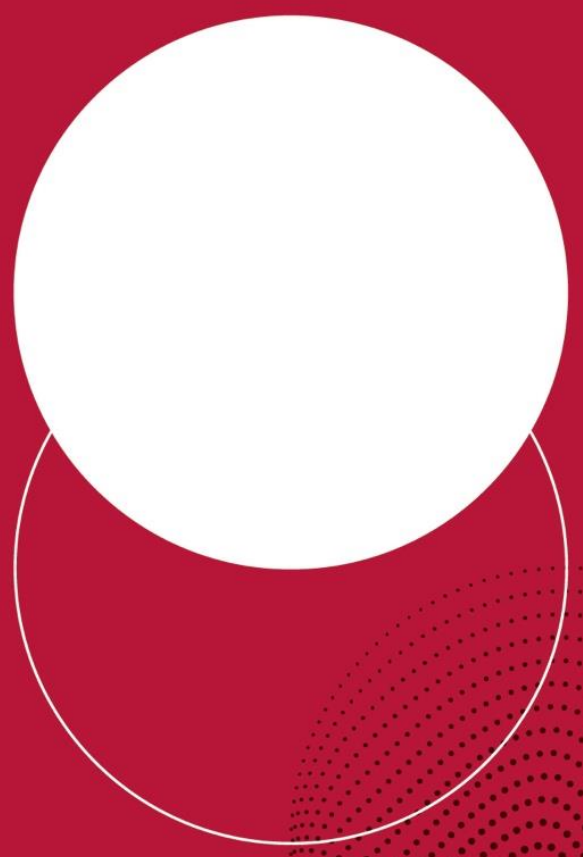

IBS WORKING PAPER 01/2017

REVISED VERSION

DECEMBER 2017

ROUTINE AND AGEING?

THE INTERGENERATIONAL DIVIDE IN

THE DEROUTINISATION OF JOBS IN

EUROPE

Piotr Lewandowski

Roma Keister

Wojciech Hardy

Szymon Górka

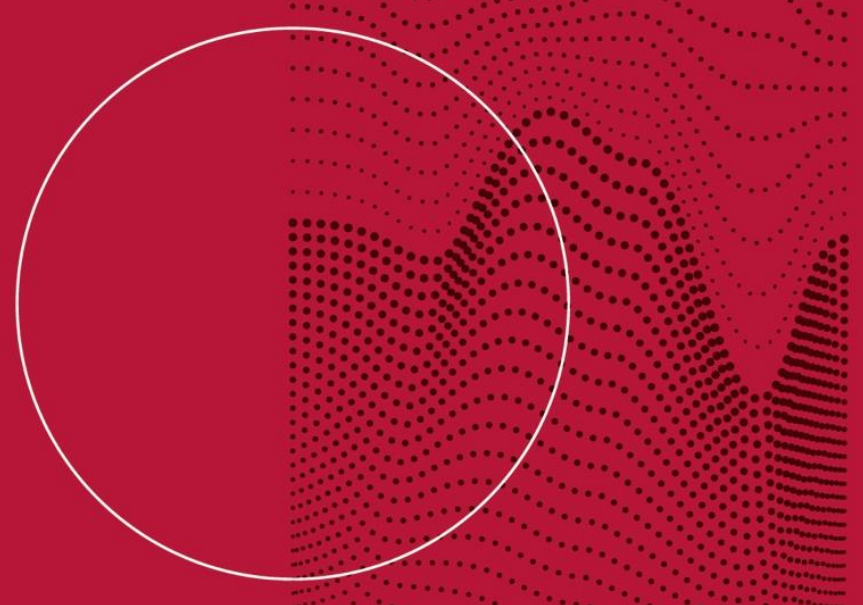




\title{
ROUTINE AND AGEING? \\ THE INTERGENERATIONAL DIVIDE IN THE DEROUTINISATION OF JOBS IN EUROPE
}

\author{
Piotr Lewandowski \\ Roma Keister* \\ Wojciech Hardy^ \\ Szymon Górka"
}

\begin{abstract}
This paper analyses the age dimension of changes in the task composition of jobs in 12 European countries between 1998 and 2015. We use the approach proposed by Autor et al. (2003) and Acemoglu \& Autor (2011), and combine $0 * N E T$ occupation content data with EU-LFS individual data to construct five task content measures: non-routine cognitive analytical, non-routine cognitive interpersonal, routine cognitive, routine manual, and non-routine manual physical. We find that the shift away from routine work and toward nonroutine work occurred much faster among workers aged between 25 and 44 than among younger workers and older workers. We find that in the majority of countries, the ageing of the workforce occurred more quickly in occupations that were initially more routine-intensive, as the share of older workers in these occupations was rising. We estimate logit models that show that individuals in these occupations were increasingly likely to be unemployed, especially if they were between the ages of 15 and 34 .
\end{abstract}

Keywords: task content of jobs, routinisation, ageing, occupational change, $0 \star N E T$

JEL: J21, J23, J24

\footnotetext{
- We thank the participants of conferences in Washington, D.C., St. Gallen, Warsaw and Saly for their insightful comments. This paper was financially supported by the Network for Jobs and Development under the auspices of the World Bank. This paper uses Eurostat data and Central Statistical Office of Poland data. Eurostat has no responsibility for the results and the conclusions, which are those of the authors. The usual disclaimers apply. All errors are ours.

- Institute for Structural Research (IBS), Warsaw, and IZA, Bonn. Corresponding author. E-mail: piotr.lewandowski@ibs.org.pl.

* Institute for Structural Research (IBS), Warsaw. E-mail: roma.keister@ibs.org.pl.

• Institute for Structural Research (IBS), Warsaw, and Faculty of Economics, University of Warsaw. E-mail: wojciech.hardy@ibs.org.pl.

• Institute for Structural Research (IBS), Warsaw. E-mail: szymon.gorka@ibs.org.pl.
} 


\section{Introduction and motivation}

One of the secular developments in the labour markets around the world over the past three decades has been the gross reallocation of labour from manual to cognitive work and the increasing importance of the nonroutine content of jobs. Since the 1970s, middle-skilled, routine jobs in the US have been in decline, whereas the employment shares of high-skilled and low-skilled workers have grown (Autor et al., 2003; Autor \& Price, 2013). Similar employment shifts, the "deroutinisation", have been occurring in Western European countries since the 1990s (Goos et al., 2014). Technological progress, especially if aimed at automating routine tasks that can be performed by machines following explicit rules, is often identified as the main reason for the hollowing-out of middle-skilled, routine employment and the polarisation of labour markets; as automation and computerisation reduce demand for workers to perform routine tasks (Autor et al., 2003; Autor et al., 2006; Acemoglu \& Autor, 2011; Brynjolfsson \& McAfee, 2014). Michaels et al. (2014) showed that in 11 OECD countries the growth of ICT has led to decreased demand for middle-educated workers, while it has resulted in increased demand for highly educated workers. Graetz \& Michaels (2015) provided evidence that robots are crowding out low-skilled workers and, to a lesser extent, middle-skilled workers. Finally, the diffusion of ICT has intensified the shift away from routine work and towards analytical and interpersonal activities (Deming, 2015; Spitz-Oener, 2006; de la Rica \& Gortazar, 2016). Offshoring is the second main factor that has contributed to the relative decline of routine-intensive, middle-skilled jobs, particularly in OECD countries (Goos et al., 2014, Hummels et al., 2016). The middle-income and the low-income countries have also been experiencing a shift away from manual work and towards cognitive work. However, routine employment, and especially routine cognitive employment, has either remained stable or even increased in the emerging South (Aedo et al., 2013), in Russia (Gimpelson \& Kapeliushnikov, 2016), and in the transition economies of Central and Eastern Europe (Hardy et al., 2016). Hardy et al. (2016) attributed this evolution of routine work in emerging economies to structural change; specifically, to a gross reallocation of labour from (highly manual) agriculture to manufacturing (industrialised countries tend to have more routine-intensive labour markets; Marcolin et al., 2016) or services (which tend to be more cognitive-intensive than other sectors). Gimpelson \& Kapeliushnikov (2016) found similar patterns in Russia.

The literature on the rise of non-routine jobs and job polarisation has largely focused on changes in the distribution of skills and education across the workforce. Other dimensions, such as age or gender, have rarely been studied. Still, Autor \& Dorn (2009) found that in the US, the age structure of occupations that exhibited a relatively high degree of routine task intensity in 1980 had aged relatively quickly by 2005 (the average age of the workers had increased more than that of other occupations) and the employment shares of these occupations had decreased. Over this period in the US, only the youngest workers experienced mobility from routine to non-routine cognitive jobs; whereas flows in the opposite direction were more common in other age groups, regardless of the workers' education levels (Autor \& Dorn, 2009). It has also been shown that the shares of inactive older workers in the US have been growing more in local labour markets that had relatively high initial shares of routine-intensive employment (Autor et al., 2015). Cortes (2016) found that since the 1990s in the US, the risk of unemployment has increased more among routine workers than among non-routine workers. Bosch \& ter Weel (2013) showed that older workers in the Netherlands have been more likely than younger workers to end up in declining occupations with relatively low shares of high-skilled workers, to face a high risk of offshoring, and to perform more routine tasks. 
Evidence has thus emerged that older people have a greater tendency than younger individuals to work in routine-intensive jobs which have declined in most countries. However, studies that have analysed changes in the task content of jobs from the age perspective, and that have also accounted for unemployment, are scarce, especially in a cross-country setting. We wish to address this gap, and aim to answer two sets of questions. 1) Has the task content of jobs evolved differently among younger and older workers in Europe? Have workers in routine-intensive occupations been getting younger or older on average than other workers? 2) Since routine work is susceptible to automation, how has the relationship between the routine intensity of tasks and the unemployment risk changed over time? Has this relationship diversified by age? To answer these questions, we analyse 12 European countries - Austria, Belgium, Czechia, Denmark, Estonia, Germany, Greece, Hungary, Poland, Spain, Sweden, and the United Kingdom - between 1998 and 2015. 'We follow Acemoglu \& Autor (2011) in distinguishing between five task contents: non-routine cognitive analytical, nonroutine cognitive interpersonal, routine cognitive, routine manual, and non-routine manual physical.

The age dimension of occupational and task content changes is important because the impact of technical progress depends on workers' skills and adaptability to innovations, which in turn differ by age. OECD (2013) showed that older people tend to have lower ICT and analytical skills than younger individuals: the shares of adults aged 55-64 who were among the best performers (Level 2 or 3) in PIAAC tests of problem-solving in technology-rich environment were very low in all of the countries surveyed, and workers aged 55-64 were found to be $10 \mathrm{pp}$. less likely on average to use information-processing skills at work than workers aged 26-54. The skills gap observed among older workers may be attributed either to the depreciation of skills over the lifecycle (Desjardins \& Warnke, 2012) or to cohort-specific effects. Some scholars have argued that the shift away from routine work and towards non-routine work is linked to the cohort-specific upskilling of the labour force, as younger workers are increasingly likely to be college or university graduates (Oesch, 2013; Salvatori, 2015; Hardy et al., 2016). Older workers tend to be offered fewer opportunities than younger workers to participate in training, as it is generally believed that older people are less willing to learn (Tempest \& Coupland, 2016). They could be also more sceptical than younger workers about the usefulness of new technologies (Morris \& Venkatesh, 2000). Aubert et al. (2006) showed that in French manufacturing firms, the introduction of new technologies reduces hiring opportunities more for older workers than for younger workers. Older workers also tend to have less between-occupation mobility than younger workers (Tempest \& Coupland, 2016), which could make it difficult for them to switch to non-routine occupations. These findings raise serious concerns, as Acemoglu \& Restrepo (2017) have found that the countries with the highest rates of automation through industrial robots are also the countries with the most rapidly ageing workforces.

The paper is structured as follows. In Section 2, we outline the methodology and the data used. In Section 3 , we present the overall and the age-specific evolutions of the task content of jobs in the analysed countries. In Section 4, we analyse the relationship between the routine intensity of jobs and the ageing of workers in particular occupations. In Section 5, we study links between the routine task intensity (RTI) of occupations and the unemployment risk, allowing for differences between countries, age groups, and over time. In Section 6, we conclude and discuss our findings.

\footnotetext{
${ }^{1}$ We selected 12 countries that represent different economic and labour market models in Europe. In principle, any country covered by the EU-LFS can be analysed. The first year of our study reflects EU-LFS data availability.
} 


\section{Data and methodology}

\subsection{Data sources}

We use the Occupational Information Network (O*NET) data and merge them with the EU-LFS data for 12 European countries - Austria, Belgium, Czechia, Denmark, Estonia, Germany, Greece, Hungary, Poland, Spain, Sweden, and the United Kingdom - in the period 1998-2015. ${ }^{2}$ We apply the International Standard Classification of Occupations (ISCO) at the 3-digit level. Because the EU-LFS data for Poland include occupation codes at the 2-digit ISCO level, we instead use the LFS data provided by the Polish statistical office which include occupations at the 3-digit ISCO level. We restrict our sample to the employed individuals aged above 15 , and unemployed individuals aged above 15 who worked at least once and provided their last occupation's code. Self-employed individuals are also included as long as their occupations are known. In order to account for possible changes in the task content within occupations, we use the 2003 and the 2014 editions of $0 * N E T$.

We use crosswalks to match the 0*NET task data for occupations (coded with an 0*NET-specific extension of SOC classification of occupations) to the EU-LFS data (coded with an ISCO classification of occupations). For the Polish LFS data, we use additional crosswalks between the Polish classification (KZiS) and the ISCO classification. ${ }^{3}$ As the EU-LFS data for our country sample contain a 3-digit level ISCO classification, we use the crosswalks for a 4-digit level of detail of the ISCO classification, and subsequently aggregate it into means of task items within a 3-digit level of detail. The ISCO classification underwent a major revision in 2011 when the ISCO-88 was supplanted by the ISCO-08. This resulted in shifts in occupational time-series, since these two classifications are not entirely comparable. In general, we made three adjustments to achieve consistent data for the entire analysed period: a recoding of tasks items for farm workers (outlined in appendix, see also Aedo et al., 2013), a recoding of tasks for (selected) occupations in wholesale and retail trade (outlined in appendix), and a general rescaling aimed at removing the break between the 2010 and the 2011 data due to the ISCO classification change (discussed in the next subsection).

\subsection{Calculating the task content of jobs}

In calculating the task content of occupations, we follow the procedure of Acemoglu \& Autor (2011). Once the 0*NET task items (from both 2003 and 2014 editions) are assigned to the EU-LFS data, we standardise the values of each task item using the country-specific means and standard deviations calculated on the first three years of data in every country. Next, using these standardised task items, we constructed five composite

\footnotetext{
${ }^{2}$ Previous studies that use $0 \star N E T$ data merged with LFS data for other countries than the US include Arias et al. (2014), Goos et al. (2013), Goos et al. (2014), Dicarlo et al. (2016), and Hardy et al. (2016). Handel (2012) showed that US occupation-based and non-US skill survey-based measures lead to very similar outcomes for European countries. Cedefop (2013) confirmed that it is methodologically valid to use 0*NET data to construct occupational measures in European countries.

${ }^{3}$ The complete set of crosswalks that we used is available online: ibs.org.pl/en/resources [accessed: 2017-01-27].
} 
task content measures: non-routine cognitive analytical, non-routine cognitive interpersonal, routine cognitive, routine manual and non-routine manual physical. Each composite task content measure is calculated as a sum of constituent task items (see Appendix A1 for the detailed description) which in the next step is again standardised to have a mean 0 and standard deviation 1 in the first three years in every country. This allows us to achieve a mean of 0 and a standard deviation of 1 over the first three years available for each country, and interpret a unit change in the mean values of task contents as a one standard deviation change since the beginning of the analysed period. Three years were chosen instead of the initial year in order to reduce the impact of potential outliers. Standardisation is required also because particular task contents use various number of items which also have different ranges (Acemoglu and Autor, 2011). In line with Arias and SánchezPáramo (2014) and Dicarlo et al. (2016) standardisation is done within each country so the results can be used to analyse changes over time in particular countries, but they cannot be used to compare levels of task content measures between countries.

Because the ISCO classification transitioned from ISCO-88 (COM) to ISCO-08 in 2011, there is a level shift of task values between 2010 and 2011. To deal with this problem, we equate the mean task values in the two years surrounding the classification changes, which allows us to study the overall changes in a consistent manner. Our approach is similar to that of Goos et al. (2014). It removes any changes in the task intensities between 2010 and 2011, while ensuring that the changes that occurred between 1998-2010 and 2011-2014 are otherwise comparable. Rescaling is conducted separately for each country and separately for two editions of $0 * N E T$ that we use. Additionally, a few countries changed their national occupational classifications over the period of the study. While the EU-LFS data contain uniform ISCO-88 (COM) and ISCO-08 classifications, they do not fully account for the changes in national classifications. In 2001, the United Kingdom updated their classification to the SOC-00, which resulted in shifts in the task content intensities. We apply the above mentioned rescaling approach to the 2001 year in the United Kingdom. Likewise, in Poland we corrected the data in accordance with the breaks of Polish classification of occupations (KZiS) in 2003, 2005, 2011 and 2015 (see Hardy et al., 2016 for more details on KZiS changes). Similarly, we rescale the Austrian data where in 2004 the survey was converted to a continuous one, covering all weeks of the year. In general, our adjustments overlap with those applied by Goos et al. (2014).

We apply a weighted average to combine the task content measures based on the 2003 0*NET and the 2014 0*NET for each occupation. From 1998 to 2003, we use task indices based on 0*NET 2003; for any year $t$ in the period 2004-2014, we assign a weight $\frac{2014-t}{11}$ to task indices based on $0^{\star}$ NET 2003, and a weight $\frac{\mathrm{t}-2003}{11}$ to task indices based on O*NET 2014; for year 2015 we use task measures based on O*NET 2014. The average level of task content calculated for a given population will be called task intensity. In order to have a common reference point, we shift the values of tasks so that the initial level of every average task intensity at the country level is equal to zero. For presentation purposes, we multiply all values by 100 . The resulting values for any task intensity in any year range from -20.6 (routine manual for Spain in 2014) to 21..8 (nonroutine cognitive analytical for Estonia in 2014), and with standard deviations varying from standard deviation is 8.4 in Austria to 11.7 in Czechia).

After calculating the task content intensities for workers, we assigned the same task content intensities to unemployed individuals based on the last job they held. For unemployed individuals who had never worked or did not provide the occupation code on their last job, the task contents are defined as missing. 


\subsection{Routine task intensity index}

Following the literature, we also construct the routine task intensity (RTI) for each occupation as the relative intensity of routine tasks, using the formula:

$$
R T I=\ln \left(r_{\text {cog }}+r_{\text {man }}\right)-\ln \left(n r_{\text {analytical }}+n r_{\text {personal }}\right)
$$

Our definition is consistent with definitions previously used in the literature (Autor \& Dorn, 2009, 2013), and in line with Goos et al. (2014) we utilise task contents defined using the O*NET data (Acemoglu \& Autor, 2011) instead of the DOT (previous occupational classification) values. This updated approach allows us to clearly distinguish between the routine and the non-routine tasks. ${ }^{4}$ It also enables us to use two types of routine tasks - cognitive and manual - as indicators of the routine task intensity. ${ }^{5}$ However, as the task measures may take negative values, prior to constructing RTI index we scale the values of five tasks content measures so that they are positive. To this end, each task content for individual $i$ is shifted by the minimum value of $j$-th task content plus 1 (to ensure that all arguments in the logarithm are positive). By design, the RTI measure increases with the importance of routine tasks, and declines with the importance of non-routine tasks.

During the 1998-2010 period, the RTI index shows negative values for high-skilled occupations, like legislators, senior officials, managers, and professionals (average of -0.30 across all countries); low positive values for occupations like technicians and associate professionals (average of 0.28 across all countries); higher positive values for clerks, service workers, shop and market sales workers, skilled agricultural and fishery workers (an average of 0.56 across all countries); and the highest values for craft and related trades workers, plant and machine operators and assemblers, and workers in elementary occupations (an average of 1.08 across all countries). The distribution of the RTI index across the whole spectrum of ISCO occupations is presented in Figure A1 in the appendix. The RTI distribution is coherent across our entire sample, as the correlations of the RTI index across occupations in any two countries in our sample range from $90 \%$ to $95 \%$.

\footnotetext{
4 "Analytical", "manual", and "routine" tasks were available in DOT (Autor \& Dorn, 2009, 2013).

${ }^{5}$ Since the intensity of routine manual tasks and the intensity of non-routine manual tasks are highly correlated (correlation ranging from 0.70 in Czechia to 0.82 in Sweden and Denmark), in our RTI measure we omit the non-routine manual content. Including these two measures would confound the RTI values. For the purposes of analysing routinebiased technological change, routine manual tasks seem more important than non-routine tasks, as there is no proof of technology directly influencing the demand for the latter.
} 


\section{Changes in the task composition of jobs by age}

The overall changes in task structures between the late 1990s and the middle 2010s were quite similar across the analysed countries and consisted of deroutinisation of jobs. In every country, the intensity of non-routine cognitive tasks rose substantially, in line with the earlier findings or Goos et al. (2014) or Hardy et al. (2016). Manual tasks, both routine and non-routine, shrank in all countries. However, the patterns of changes in routine cognitive tasks varied across our sample (Figure 1). In seven out of the 12 analysed countries, the intensity of routine cognitive tasks declined (to the greatest extent in the UK, Belgium and Sweden). However, the intensity of routine cognitive tasks increased in five countries: in all CEE countries in our sample except for Hungary (to the largest extent in Estonia and Poland), as well as in in Greece and Spain). Hardy et al. (2016) found similar trends in four other CEE countries (Croatia, Latvia, Lithuania, Romania), and attributed the differences in the evolution of routine cognitive tasks in the UE15 and CEE countries to different patterns of structural change that these countries underwent, in particular to the gross reallocation of labour from agriculture (intensive in manual tasks) to services (rich in routine cognitive tasks) in the CEE.

Figure 1. Total changes in the task intensity of jobs between 1998-2000 and 2013-2015 in selected European countries.

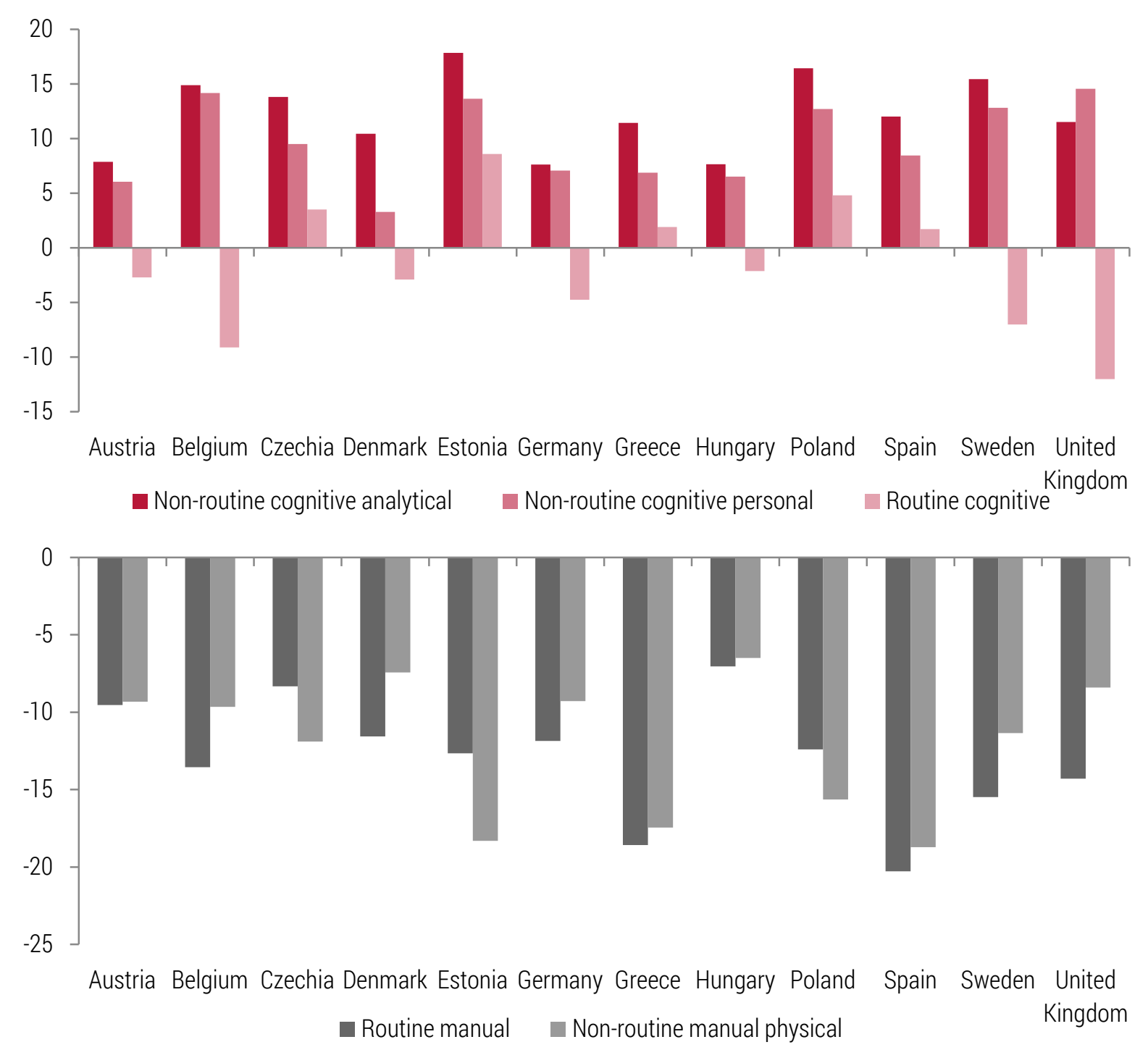

Source: Own calculations based on EU-LFS and O*NET data. 
Importantly, the changes in the task content of jobs varied substantially across age groups. They were the fastest among prime-aged workers (25-44 years) and much slower, or even opposite to the overall trend among the young (15-24 years) and older (45-64 years) workers. This pattern is illustrated by the estimates of time trends in task intensity of particular age groups, in panel regressions (Table 1) and country specific regressions (Figure A2 in the appendix).

Prime-age workers (e.g. aged 25-44) recorded the fastest growth of the intensity of non-routine cognitive tasks. The trend was steeper for analytical tasks (the average of panel estimates in this age group is 1.1 which means an annual growth of 1.1) than for personal tasks (0.7). Estonia, Poland and Sweden recorded the fastest growth of the intensity of both non-routine cognitive tasks among prime-aged workers. By contrast, the trend of intensity of analytical tasks among workers aged 15-24 was negative in a panel $(-0.3)$ and in 7 out of 12 analysed countries (Denmark, Sweden and the UK exhibited the strongest decline among young workers, with estimated trends of $-3.6,-3.1$ and -1.4, respectively). The gap between trends in analytical tasks among prime-aged workers and young workers was the largest in Denmark and Sweden. On the other hand, Austria and Spain were the only countries where the growth of analytical task intensity among young workers was higher than the growth among prime-aged workers. In the case of personal tasks, the differences between prime-aged and young workers were similar but less pronounced. The trend in intensity of these tasks among young workers was positive in a panel (0.4) and in 10 out of 12 countries (Figure A2). Among workers aged 4564 , the intensity of both non-routine tasks was growing but the trends were about half of those recorded among workers aged 25-44. The difference between older and prime-aged workers was the largest in CEE countries (Estonia, Hungary, Poland). The United Kingdom was the only country where the intensity of both non-routine cognitive tasks grew faster among older workers than among prime-aged workers.

Table 1. Time-trend coefficients from fixed-effects panel regressions on the task content intensities in 5-year age groups

\begin{tabular}{|c|c|c|c|c|c|c|c|c|c|c|}
\hline & $15-19$ & $20-24$ & $25-29$ & $30-34$ & $35-39$ & $40-44$ & $45-49$ & $50-54$ & $55-59$ & $60-64$ \\
\hline $\begin{array}{c}\text { Non-routine cognitive } \\
\text { analytical }\end{array}$ & $-0.46^{\star \star \star}$ & $-0.13^{\star}$ & $0.93^{\star \star \star}$ & $1.40^{\star \star \star}$ & $1.27^{\star \star \star}$ & $0.96^{\star \star \star}$ & $0.60^{\star \star \star}$ & $0.21^{\star \star \star}$ & $0.36^{\star \star \star}$ & $0.65^{\star \star \star}$ \\
& $(0.00)$ & $(0.05)$ & $(0.00)$ & $(0.00)$ & $(0.00)$ & $(0.00)$ & $(0.00)$ & $(0.00)$ & $(0.00)$ & $(0.00)$ \\
\hline \multirow{2}{*}{$\begin{array}{c}\text { Non-routine cognitive personal } \\
\text { Routine cognitive }\end{array}$} & $0.44^{\star \star \star}$ & $0.39^{\star \star \star}$ & $0.63^{\star \star \star}$ & $0.80^{\star \star \star}$ & $0.82^{\star \star \star}$ & $0.72^{\star \star \star}$ & $0.60^{\star \star \star}$ & $0.30^{\star \star \star}$ & $0.22^{\star \star \star}$ & -0.07 \\
& $(0.00)$ & $(0.00)$ & $(0.00)$ & $(0.00)$ & $(0.00)$ & $(0.00)$ & $(0.00)$ & $(0.00)$ & $(0.00)$ & $(0.53)$ \\
\hline \multirow{2}{*}{ Routine manual } & 0.23 & $-0.15^{\star \star}$ & $-0.37^{\star \star \star}$ & $-0.28^{\star \star \star}$ & $-0.25^{\star \star \star}$ & $-0.23^{\star \star \star}$ & $-0.13^{\star \star \star}$ & $0.15^{\star \star \star}$ & $0.59^{\star \star \star}$ & $1.37^{\star \star \star}$ \\
& $(0.15)$ & $(0.03)$ & $(0.00)$ & $(0.00)$ & $(0.00)$ & $(0.00)$ & $(0.00)$ & $(0.00)$ & $(0.00)$ & $(0.00)$ \\
\hline \multirow{2}{*}{ Non-routine manual physical } & $-0.68^{\star \star \star}$ & $-0.83^{\star \star \star}$ & $-1.23^{\star \star \star}$ & $-1.33^{\star \star \star}$ & $-1.14^{\star \star \star}$ & $-0.86^{\star \star \star}$ & $-0.61^{\star \star \star}$ & $-0.31^{\star \star \star}$ & $-0.37^{\star \star \star}$ & $-0.31^{\star \star \star}$ \\
& $(0.00)$ & $(0.00)$ & $(0.00)$ & $(0.00)$ & $(0.00)$ & $(0.00)$ & $(0.00)$ & $(0.00)$ & $(0.00)$ & $(0.00)$ \\
\hline
\end{tabular}

Note: Each coefficient was estimated in a separate panel regression with a particular task content intensity (rows) in a given age group (columns) as the explained variable and time-trend as the control variable. P-value in parentheses. ${ }^{* *} p<0.01,{ }^{* *} p<0.05,{ }^{*} p<0.1$. Source: Own estimations based on EU-LFS and O*NET data.

The shift away from routine cognitive tasks was the most pronounced among prime-aged workers (average panel trend of -0.3). However, in Central and Eastern, as well as in Southern European countries where the average intensity of routine cognitive tasks increased, the trend of routine cognitive task intensity was positive even among prime-aged workers. The trends among young workers were insignificant or barely negative in the 15-19 age group, and moderately negative in the 20-24 age group. On the other hand, the 
intensity of routine cognitive tasks among older workers was increasing (0.5), especially among workers aged 55 or more. In particular, workers aged 60-64 recorded the fastest increase (panel trend of 1.3). Poland stood out with the fastest growth of routine cognitive tasks among workers aged 60-64 (4.0). Had this not been for Poland, the trend in a panel for this age group would have stood at 1.1. Germany, Sweden and the United Kingdom are the only countries where the intensity of routine cognitive tasks among workers aged 45-64 was declining (Figure A2 in appendix).

The intensity of manual tasks was declining in all age groups, but the decline was the fastest among primeaged workers (the average panel trend of -1.1 for routine manual tasks and -1.0 for non-routine manual tasks). Among young workers, the decline of routine manual tasks was slightly faster than the decline of non-routine manual tasks (-0.8 and -0.3 , respectively), while the opposite was true among the older workers $(-0.4$ and -0.6 , respectively). Czechia and Hungary are the only countries where the intensity of manual tasks increased for some age groups (15-19, 55-59, and 60-64, see Figure A2).

In order to shed more light on the differences in the deroutinisation among young, prime-aged and older workers, we analyse the changes in employment of highly routine and highly non-routine workers in particular age groups. To this end, for each country we calculate the distribution of country-specific RTI index (defined in the Section 2.3) in the pooled sample covering the period of 1998-2015. We identify quartiles of the pooled, country-specific RTI distributions which we then aggregate into three categories, labelled as follows: nonroutine workers ( $1^{\text {st }} \mathrm{RTI}$ quartile), routine workers ( $4^{\text {th }} \mathrm{RTI}$ quartile) and other workers ( $2^{\text {nd }}$ and $3^{\text {rd }} \mathrm{RTI}$ quartiles, see Marcolin et al., 2016 for a similar approach). Next, we calculate the number of workers in each category by 10-year age groups and divide it by the total population in that age group in the same year. As a result we obtain the age-specific employment rates of routine, non-routine and other workers, which sum up to the total employment rate of a particular age group in a given year. Table 2 shows average changes in these employment rates between the late 1990s and the middle 2000s, while Table A4 in appendix presents results for particular countries.

Table 2. Changes in employment rates of routine and non-routine workers, by 10-year age groups between 1998-2000 and 2013-2015. Unweighted cross-country average, in pp.

\begin{tabular}{|c|c|c|c|c|c|}
\hline & $15-24$ & $25-34$ & $35-44$ & $45-54$ & $55-64$ \\
\hline Non-routine employment (1st RTI quartile) & -0.15 & 2.26 & 3.16 & 1.35 & 3.81 \\
\hline Others (2nd and 3rd RTI quartiles) & -0.67 & 4.08 & 4.34 & 6.24 & 9.31 \\
\hline Routine employment (4 ${ }^{\text {th }}$ RTI quartile) & -4.11 & -6.52 & -5.28 & -2.69 & 1.09 \\
\hline Total employment rate change & -4.93 & -0.18 & 2.22 & 4.90 & 14.21 \\
\hline
\end{tabular}

Source: Own calculations based on EU-LFS and O*NET data.

There are two factors behind the slower deroutinisation among the oldest workers (aged 55-64) in comparison to the prime-aged workers (aged 25-44). First, the oldest workers are the only age group which saw an increase of routine employment rate, on average by 1.1 pp. between 1998 and 2015. The routine employment rate among workers aged 55-64 increased in eight out of 12 countries studied, and Poland and Hungary stood out with the equal to 6.1 pp. and 6.9 pp., respectively (see Table A4 in appendix). Second, although the nonroutine employment rate also increased among the oldest workers (by $3.8 \mathrm{pp}$. on average), its growth accounted only for a small share (27\%) of the total increase of employment rate of the 55-64 age group (14.2 pp. on average). The total employment rate workers aged 55-64 increased in all countries except Greece, but 
only in the United Kingdom more than $40 \%$ of this growth can be attributed to the growth on non-routine employment rate. It was the growth in the "other workers" category that contributed most to the increase of the total employment rate among the oldest workers.

In all countries studied, the total employment rate change was the highest among the oldest workers. This secular improvement in employment rate of older workers can be related largely to retirement age and pension reforms aimed at prolonging the working lives (OECD, 2017). The oldest workers were the only age group that enjoyed employment growth across the spectrum of routine intensity of work, especially those with more routine-intensive jobs. Meanwhile, the increase of non-routine employment rate among prime-aged workers (3.2 pp. among those aged 35-44, 2.3 pp. among those aged 25-34) was greater than the increase in the total employment rate of these workers ( $2.2 \mathrm{pp}$. among those aged 35-44, $-0.2 \mathrm{pp}$. among those aged 2534). Likewise, prime-aged workers saw a steep decline in the routine employment rate (by $5.3 \mathrm{pp}$. among those aged 35-44, by $6.5 \mathrm{pp}$. among those aged 25-34.), which reinforced the relative growth of non-routine employment. This pattern was recorded in all countries except Spain (Table A4). On the other hand, the youngest workers (aged 15-24) experienced a decline of total employment rate (on average and in nine out of 12 countries) which to a large extent can be attributed to the decline of routine employment rate.

\section{Ageing of routine occupations}

In order to ascertain whether the evolution of the age structure of occupations has been related to their routine intensity, we follow the approach used by Autor \& Dorn (2009). We regress the change in the mean age of a job on its routine task intensity (RTI, as defined in the subsection 2.4). We estimate the country-specific OLS regressions of the change in the mean age of workers in various occupations between 1998 and 2010 (at the ISCO-88 3-digit levels) on the initial (1998) RTI level in occupations and the changes in occupational employment shares between 1998 and 2010. We study the changes between 1998 and 2010. The period of analysis is shorter than in the previous section, because the changes within occupations can be analysed only for a period when a given classification of occupations was used It is not possible to fully and consistently map the ISCO-88 occupations (valid between 1998 and 2010) to the ISCO-08 occupations (valid between 2011 and 2015) at the 3-digit level. Therefore, we study the changes between 1998 and 2010 (the 2011-2015 period is too short to perform a credible analysis of the ageing of occupations).

Table 3. The relationship between the routine intensity (RTI) in 1998 and the changes in the mean ages of workers in occupations between 1998 and 2010. Country-specific OLS regressions at the occupation level

\begin{tabular}{|c|c|c|c|c|c|c|c|c|c|c|c|c|}
\hline & Austria & Belgium & Czechia & Denmark & Estonia & Germany & Greece & Hungary & Poland & Spain & Sweden & UK \\
\hline RTI & $\begin{array}{c}-0.82^{\star} \\
(0.07)\end{array}$ & $\begin{array}{c}0.74^{\star \star \star} \\
(0.01)\end{array}$ & $\begin{array}{c}1.08^{\star \star \star} \\
(0.00)\end{array}$ & $\begin{array}{c}1.08^{\star \star} \\
(0.02)\end{array}$ & $\begin{array}{c}0.31 \\
(0.65)\end{array}$ & $\begin{array}{c}0.54^{\star \star} \\
(0.04)\end{array}$ & $\begin{array}{c}0.16 \\
(0.56)\end{array}$ & $\begin{array}{c}1.48^{\star \star \star} \\
(0.00)\end{array}$ & $\begin{array}{c}1.49^{\star \star \star} \\
(0.00)\end{array}$ & $\begin{array}{c}0.63^{\star} \\
(0.06)\end{array}$ & $\begin{array}{c}0.18 \\
(0.45)\end{array}$ & $\begin{array}{c}0.55 \\
(0.17)\end{array}$ \\
\hline SShare & $\begin{array}{c}0.64^{\star \star \star} \\
(0.00)\end{array}$ & $\begin{array}{c}0.20 \\
(0.30)\end{array}$ & $\begin{array}{c}-0.51^{\star} \\
(0.06)\end{array}$ & $\begin{array}{c}0.40^{\star} \\
(0.08)\end{array}$ & $\begin{array}{c}1.22^{\star \star \star} \\
(0.01)\end{array}$ & $\begin{array}{c}-0.45 \\
(0.15)\end{array}$ & $\begin{array}{c}0.11 \\
(0.13)\end{array}$ & $\begin{array}{c}0.20 \\
(0.39)\end{array}$ & $\begin{array}{c}0.21^{\star} \\
(0.05)\end{array}$ & $\begin{array}{c}0.08 \\
(0.74)\end{array}$ & $\begin{array}{c}-0.71^{\star} \\
(0.08)\end{array}$ & $\begin{array}{c}-0.45^{\star \star} \\
(0.05)\end{array}$ \\
\hline No. of obs. & 100 & 101 & 104 & 102 & 100 & 102 & 100 & 102 & 101 & 102 & 103 & 89 \\
\hline$R^{2}$ & 0.16 & 0.07 & 0.14 & 0.08 & 0.08 & 0.09 & 0.03 & 0.12 & 0.15 & 0.04 & 0.04 & 0.09 \\
\hline
\end{tabular}

Note: : Each coefficient was estimated in a country-specific regression with the change in the average age of workers in a given occupation as the explained variable, and the initial (1998) RTI and the change in share of occupation in total employment as control variables. P-value in parentheses. *** $p<0.07,{ }^{*} p<0.05, * p<0.7$.

Source: Own estimations based on EU-LFS and O*NET data. 
Our results show that in seven out of 12 analysed countries, the higher the routine task intensity of an occupation was in 1998, the greater was the change in the average age of the workers in this occupation by 2010 (see Table 3). No significant relationship was observed in Austria, Greece, Sweden, Estonia or the UK. The main reason why the age structure of routine jobs grew older more quickly was the declining share of workers in the youngest age groups and the increasing share of older age groups in these occupations. In seven out of the 12 analysed countries, the higher the initial routine intensity of an occupation was, the more significantly negative was the change in the share of workers in the youngest age group (aged 15-24) in this occupation (Table 4). Additionally, in eight countries a higher initial RTI was associated with a significantly higher increase in the share of workers aged 45-64. Moreover, in five countries it was associated with a declining share of workers aged 24-44. Greece and Spain stand out as the only countries were the share of prime-aged workers was increasing in a more routine occupations.

Our findings are in line with results for the US (Autor \& Dorn, 2009), which showed that higher routine intensity of an occupation was associated with a decreasing share of the youngest workers and an increasing share of the oldest workers, although there was no significant relationship with share of the prime-aged workers. Autor \& Dorn (2009) also found a negative relationship between the change in the average age of the workers in an occupation and the change in the occupation's share of overall employment. In our sample, only Czechia, Estonia, Sweden and the UK exhibited such a trade-off. In Austria, Denmark, and Poland, the change in the average age of the workers and the change in the employment share of a given occupation were positively related. In the remaining five countries, this relationship was not significant.

Table 4. The relationship between the routine intensity (RTI) in 1998 and the changes in the shares of age groups within occupations. Country-specific OLS regressions at the occupation level

\begin{tabular}{|c|c|c|c|c|c|c|c|c|c|c|c|c|}
\hline & Austria & Belgium & Czechia & Denmark & Estonia & Germany & Greece & Hungary & Poland & Spain & Sweden & UK \\
\hline $\begin{array}{c}\Delta \\
15-24\end{array}$ & $\begin{array}{c}0.01 \\
(0.29)\end{array}$ & $\begin{array}{l}-0.01^{\star} \\
(0.07)\end{array}$ & $\begin{array}{c}-0.03^{\star \star \star} \\
(0.00)\end{array}$ & $\begin{array}{l}-0.01 \\
(0.20)\end{array}$ & $\begin{array}{l}-0.01 \\
(0.30)\end{array}$ & $\begin{array}{c}0.00 \\
(0.68)\end{array}$ & $\begin{array}{c}-0.04 \star \star \star \\
(0.00)\end{array}$ & $\begin{array}{c}-0.04^{\star \star \star} \\
(0.00)\end{array}$ & $\begin{array}{c}-0.02 \star \star \star \\
(0.00)\end{array}$ & $\begin{array}{c}-0.06 \star \star \star \\
(0.00)\end{array}$ & $\begin{array}{c}0.00 \\
(0.61)\end{array}$ & $\begin{array}{l}-0.01^{\star} \\
(0.09)\end{array}$ \\
\hline $\begin{array}{c}\Delta \\
25-44\end{array}$ & $\begin{array}{c}0.02 \\
(0.20)\end{array}$ & $\begin{array}{c}-0.03^{\star \star \star} \\
(0.01)\end{array}$ & $\begin{array}{l}-0.02 \\
(0.24)\end{array}$ & $\begin{array}{c}-0.05^{\star \star \star} \\
(0.01)\end{array}$ & $\begin{array}{c}0.01 \\
(0.78)\end{array}$ & $\begin{array}{c}-0.04^{\star \star \star} \\
(0.00)\end{array}$ & $\begin{array}{l}0.06^{\star \star \star} \\
(0.00)\end{array}$ & $\begin{array}{c}0.01 \\
(0.54)\end{array}$ & $\begin{array}{c}-0.04^{\star \star \star} \\
(0.00)\end{array}$ & $\begin{array}{l}0.06^{\star \star \star} \\
(0.00)\end{array}$ & $\begin{array}{l}-0.02^{\star \star \star} \\
(0.01)\end{array}$ & $\begin{array}{l}-0.01 \\
(0.34)\end{array}$ \\
\hline $\begin{array}{c}\Delta \\
45-64\end{array}$ & $\begin{array}{l}-0.03^{\star} \\
(0.06)\end{array}$ & $\begin{array}{c}0.04 \star \star \star \\
(0.00)\end{array}$ & $\begin{array}{c}0.04^{\star \star \star} \\
(0.00)\end{array}$ & $\begin{array}{l}0.06^{\star \star \star} \\
(0.00)\end{array}$ & $\begin{array}{c}0.01 \\
(0.80)\end{array}$ & $\begin{array}{l}0.04^{\star \star \star} \\
(0.00)\end{array}$ & $\begin{array}{l}-0.02^{\star} \\
(0.08)\end{array}$ & $\begin{array}{l}0.03^{\star \star} \\
(0.03)\end{array}$ & $\begin{array}{c}0.07 \star \star \star \\
(0.00)\end{array}$ & $\begin{array}{l}-0.00 \\
(0.85)\end{array}$ & $\begin{array}{l}0.02^{\star \star} \\
(0.02)\end{array}$ & $\begin{array}{l}0.02^{\star} \\
(0.08)\end{array}$ \\
\hline $\begin{array}{l}\text { No. of } \\
\text { obs. }\end{array}$ & 100 & 101 & 104 & 102 & 100 & 102 & 100 & 102 & 101 & 102 & 103 & 89 \\
\hline
\end{tabular}

Note: Each coefficient was estimated in a country-specific OLS regression with the change (1998 to 2010) in the share of a particular age group of workers in a given occupation as the explained variable (rows), and the initial (1998) RTI and the change in share of occupation in total employment as control variables. For brevity, only the coefficients related to RTI are reported. $P$-value in parentheses. ${ }^{* *} p<0.01,{ }^{* *} p<0.05,{ }^{*} p<0.1$.

\section{Source: Own estimations based on EU-LFS and O*NET data.}

Moreover, we find that in several countries the change in the mean age of an occupation was negatively related to the intensity of non-routine cognitive tasks (both analytical and personal, cf. Table 5). This relationship was strongest in Czechia, Hungary, and Poland - three out of four of the post-transition economies in our sample - as well as in Denmark. In Estonia, Greece, Sweden, and the United Kingdom we find no significant relationship between the initial intensity of non-routine cognitive tasks and changes in the age structure of workers in particular occupations. Austria stands out as being the only country for which there was a positive relationship between these two variables. 
Table 5. The relationship between the intensity of non-routine cognitive analytical (NRCA) and non-routine cognitive personal (NRCP) tasks in 1998 and the changes in the mean ages of workers in occupations between 1998 and 2010. Country-specific OLS regressions at the occupation level

\begin{tabular}{|c|c|c|c|c|c|c|c|c|c|c|c|c|}
\hline & Austria & Belgium & Czechia & Denmark & Estonia & Germany & Greece & Hungary & Poland & Spain & Sweden & UK \\
\hline NRCA & $\begin{array}{c}0.68^{\star \star \star} \\
(0.00)\end{array}$ & $\begin{array}{l}-0.23 \\
(0.13) \\
\end{array}$ & $\begin{array}{c}-0.47^{\star \star} \\
(0.01)\end{array}$ & $\begin{array}{l}-0.41^{\star} \\
(0.09)\end{array}$ & $\begin{array}{l}-0.39 \\
(0.31)\end{array}$ & $\begin{array}{l}-0.24^{\star} \\
(0.08)\end{array}$ & $\begin{array}{c}0.17 \\
(0.27)\end{array}$ & $\begin{array}{c}-0.76^{\star \star \star} \\
(0.00)\end{array}$ & $\begin{array}{l}-0.58^{\star \star} \\
(0.02)\end{array}$ & $\begin{array}{l}-0.32^{\star} \\
(0.08)\end{array}$ & $\begin{array}{l}-0.09 \\
(0.44)\end{array}$ & $\begin{array}{l}-0.05 \\
(0.80) \\
\end{array}$ \\
\hline NRCP & $\begin{array}{l}0.50^{\star \star} \\
(0.23) \\
\end{array}$ & $\begin{array}{l}-0.30^{\star} \\
(0.15)\end{array}$ & $\begin{array}{c}-0.44^{\star \star} \\
(0.18) \\
\end{array}$ & $\begin{array}{c}-0.47 \star \star \\
(0.24)\end{array}$ & $\begin{array}{l}-0.19 \\
(0.38) \\
\end{array}$ & $\begin{array}{c}-0.31^{\star \star} \\
(0.14)\end{array}$ & $\begin{array}{c}0.07 \\
(0.14) \\
\end{array}$ & $\begin{array}{c}-0.65^{\star \star \star} \\
(0.23) \\
\end{array}$ & $\begin{array}{c}-0.62^{\star \star \star} \\
(0.22)\end{array}$ & $\begin{array}{l}-0.23 \\
(0.18) \\
\end{array}$ & $\begin{array}{l}-0.07 \\
(0.12) \\
\end{array}$ & $\begin{array}{l}-0.14 \\
(0.22) \\
\end{array}$ \\
\hline
\end{tabular}

Note: Each coefficient was estimated in a country-specific regression with the change in the average age of workers in a given occupation as the explained variable, and the specific task content measure (rows) and the change in share of occupation in total employment as control variables. For brevity, only the coefficients related to the task content intensities are reported. P-value in parentheses. ${ }^{* *} p<0.07,{ }^{* *} p<0.05,{ }^{*} p<0.7$.

Source: Own estimations based on EU-LFS and O*NET data.

In order to verify if the above findings hold for the changes between 1998 and 2015 we re-estimate all regressions reported in Tables 3-5 as pooled regressions at the 1-digit occupation level (nine occupations per country, 108 observations) with country fixed effects. ${ }^{6}$ Results are presented in Table A5 in appendix. We find that a higher routine intensity of an occupation in 1998 was associated with a larger increase in the average age of worker in a given occupation by 2015 (coefficient 0.83 significant at 1\% level), a stronger decline in the share of workers aged $15-24(-0.02,1 \%$ level) and a higher increase in the share of workers aged $45-64(0.03$, $1 \%$ level), while there was no significant association with the share of workers aged 25-44. The relationship between the intensity of particular non-routine cognitive task in occupations in 1998 and the increase in the average age of worker in a given occupation by 2015 was negative for both analytical and interpersonal tasks $(-0.53$ and -0.35 , respectively, both significant at $1 \%$ level). The more routine occupations were indeed ageing faster in Europe.

\section{Routine intensity and the risk of unemployment}

In the previous sections, we showed that in European countries, the manual and the routine content of jobs declined between the late 1990s and the mid-2010s, and that the younger workers experienced these changes at a faster pace than the older workers. Because such occupational developments are often attributed to demand-side factors, such as routine-biased technological change or offshoring (Autor et al.; 2003, Michaels et al.; 2014, Goos et al.; 2014), they may be associated with an increase in the unemployment risk of routine workers. Using panel data, Cortes (2016) found evidence that this was indeed the case in the US. Unfortunately, panel datasets cannot be constructed using the EU-LFS, and are not available for the group of countries we are studying. Nevertheless, in this section we use the cross-section LFS data to analyse the relationship between the routine task intensity (RTI) of occupations and the unemployment risk. Our sample includes employed individuals and unemployed individuals who worked at least once in the past, and who provided the occupation code of their last job. ${ }^{7}$

\footnotetext{
${ }^{6}$ Occupations in ISCO-88 (valid until 2010) and ISCO-08 (valid since 2011) are entirely comparable only a the 1-digit level.

${ }^{7}$ We might be concerned about potential omitted variable and selection issues related to the missing data on occupations. However, the shares of the unemployed who worked at least once and did not report the occupational code
} 


\subsection{Routine task intensity and occupation-specific unemployment rates}

We define the annual occupation-specific unemployment rates as the share of the unemployed whose last job was in a given occupation in the labour supply in this occupation (i.e., the sum of unemployed individuals whose last job was in a given occupation and employed individuals currently working in this occupation). For each country, we regress the change in the occupation-specific unemployment rates between 1998 and 2010 on the RTI of an occupation in 1998 (see Table 6).

In six out of the 12 countries in our sample, the changes in the occupation-specific unemployment rates between 1998 and 2010 were significantly and positively associated with the occupation-specific routine intensities (RTIS) in 1998. In other words, the more routine the occupation was in 1998, the greater the change was in the occupation-specific unemployment rate over the next 16 years. In three of these countries Estonia, Greece, and Sweden - this pattern was accompanied by rising unemployment rates across all occupations (as evidenced by a significant and positive constant). In the other three countries - Czechia, Denmark, and Spain - there was no general trend in the occupation-specific unemployment rates (the constant was insignificant). In Belgium and Germany, the relationship between the RTI in 1998 and the change in the occupation-specific unemployment rates was negative (Germany also recorded a significant decline in unemployment rates across all occupations). In the remaining four countries, there was no significant link between the RTI in 1998 and the change in the occupation-specific unemployment rates between 1998 and 2010.

Table 6. The relationship between the routine intensity (RTI) in 1998 and the changes in the occupation-specific unemployment rates between 1998 and 2010. Country-specific OLS regressions at the occupation level

\begin{tabular}{|c|c|c|c|c|c|c|c|c|c|c|c|c|}
\hline & Austria & Belgium & Czechia & Denmark & Estonia & Germany & Greece & Hungary & Poland & Spain & Sweden & UK \\
\hline $\mathrm{RTI}$ & $\begin{array}{c}0.24 \\
(0.60) \\
\end{array}$ & $\begin{array}{c}-1.27^{\star \star \star} \\
(0.01)\end{array}$ & $\begin{array}{c}6.64 * \star \star \\
(0.00) \\
\end{array}$ & $\begin{array}{c}4.01^{\star \star \star} \\
(0.00)\end{array}$ & $\begin{array}{c}6.17^{\star \star \star} \\
(0.00) \\
\end{array}$ & $\begin{array}{c}-2.37^{\star \star \star} \\
(0.00)\end{array}$ & $\begin{array}{c}2.93^{\star \star \star} \\
(0.00) \\
\end{array}$ & $\begin{array}{c}0.72 \\
(0.23) \\
\end{array}$ & $\begin{array}{c}1.59 \\
(0.45) \\
\end{array}$ & $\begin{array}{c}6.91 \star \star \star \\
(0.00) \\
\end{array}$ & $\begin{array}{c}1.93^{\star \star \star} \\
(0.00)\end{array}$ & $\begin{array}{c}0.10 \\
(0.80)\end{array}$ \\
\hline $\begin{array}{c}\text { Consta } \\
\mathrm{nt}\end{array}$ & $\begin{array}{c}1.07^{\star \star \star} \\
(0.34) \\
\end{array}$ & $\begin{array}{c}0.49 \\
(0.36) \\
\end{array}$ & $\begin{array}{l}-1.76^{\star} \\
(1.00) \\
\end{array}$ & $\begin{array}{c}0.51 \\
(0.50) \\
\end{array}$ & $\begin{array}{c}2.65^{\star \star \star} \\
(1.01) \\
\end{array}$ & $\begin{array}{c}-1.48 * \star \star \\
(0.40)\end{array}$ & $\begin{array}{c}2.23^{\star \star \star} \\
(0.52) \\
\end{array}$ & $\begin{array}{l}1.18^{\star \star} \\
(0.49) \\
\end{array}$ & $\begin{array}{l}-0.43 \\
(1.80) \\
\end{array}$ & $\begin{array}{c}0.23 \\
(0.94) \\
\end{array}$ & $\begin{array}{c}1.16^{\star \star \star} \\
(0.35) \\
\end{array}$ & $\begin{array}{c}0.84^{\star \star \star} \\
(0.31) \\
\end{array}$ \\
\hline $\begin{array}{l}\text { No. of } \\
\text { obs. }\end{array}$ & 100 & 101 & 104 & 102 & 100 & 102 & 100 & 102 & 102 & 102 & 103 & 89 \\
\hline
\end{tabular}

Note: Each coefficient was estimated in a country-specific OLS regression with the change (1998 to 2010) in the occupation-specific unemployment rate as the explained variable and the initial (1998) RTI as a control variable. Occupation-specific unemployment rates are calculated by dividing the number of unemployed individuals whose last job was in a given occupation by the labour supply in a given occupation (the sum of employment in a given occupation and the number of unemployed individuals whose last job was in a given occupation). The regressions are weighted with the size of the occupational labour supply (sum of employed and unemployed individuals). Due to data availability, the reference period is $1999-2001$ for Germany and the United Kingdom and is 2003-2005 for Sweden. P-value in parentheses. ${ }^{* *} p<0.07,{ }^{* *} p<0.05,{ }^{*} p<0.1$.

Source: Own estimations based on EU-LFS and O*NET data.

of their last job are small - below $2 \%$ in all countries (see Table A3 in the appendix). The unemployed individuals who had never worked were not surveyed about their occupations, so we had to exclude them as well. The underlying assumption is that an occupation can be assigned to a worker only if she or he has ever worked in that occupation. 


\subsection{Routine task intensity and individual unemployment risk}

In the next step, we analyse the relationship between the routine task intensity, the risk of unemployment, and age. In order to study how this relationship evolved over time, we use individual EU-LFS data for the first three available years (1998-2000) and for the last three available years (at the time of writing, these years are 20132015). We estimate country-specific logit models with unemployment as the explained variable (relative to employment) on the sample without self-employed individuals. In the first version of the model, we include the RTI and the time dummy for the 2013-2015 period as the explanatory variables. In the second version of the model, we add a standard set of socio-demographic controls (age, gender, marital status, education level). In the third version, we add two regional controls calculated using the Cambridge Econometrics European Regional Data. In order to account for the regional differences in the prevalence of routine jobs, we assign to each individual the regional employment share of industry (manufacturing and mining, the sector with the highest RTI values) at the time when the individual was in high school (aged 15-19), or the earliest available data. ${ }^{8}$ We follow Fletcher \& Sindelar (2009), who showed that the regional shares of blue-collar jobs affect the probability that an individual will decide to pursue a blue-collar occupation. ${ }^{9}$ We also control for regional labour demand shocks with Bartik (1991) shocks. In the EU-LFS, the regional data are available on the NUTS2 or the NUTS1 level (see Table A6 in the appendix). In the fourth version of the model, we account for the heterogeneity of the RTI effects by age. To this end, we include interactions between the RTI and 10-year age group dummies. We include interactions between the RTI and a dummy variable for the period 2013-2015 in all of the regressions; and in the fourth version of the model we also interact the age-specific RTI variable with the 2013-2015 period dummy. The results of models 1-3 are presented in Table 7, and the results of model 4 are presented in Figure 3 and in Table A7 in the appendix. ${ }^{10}$

We find that in all of the countries studied the individuals in the more routine-intensive occupations were more likely to be unemployed. The odds ratios associated with the RTI in the simple model 1 are higher than one and are highly significant in all countries. Once we control for socio-demographic characteristics (model 2), the odds ratios associated with the RTI decline in all countries, but they remain highly significant in all countries except Spain. The inclusion of two regional controls (model 3) that account for past industrial structures and local labour demand shocks, respectively, does not substantially affect the effect of the RTI. The relationship between RTI and the risk of unemployment seems to be rather constant over time. Although the odds ratios related to the interaction between the RTI and the period 2013-2015 dummy are greater than one in nine out of 12 countries, only in Spain and Sweden these interactions are statistically significant (in all three models).

\footnotetext{
${ }^{8}$ The Cambridge Econometrics European Regional Data cover the 1980-2014 period for the Western European countries, and the 1990-2014 period for the Central and Eastern European countries. We assign the 1980 shares to all individuals born before 1965 in Western European countries, and the 1990 shares to all individuals born before 1975 in the Central and Eastern European countries. We assign the 2014 shares to all individuals aged between 15 and 19 in 2015.

${ }^{9}$ Unlike Fletcher \& Sindelar (2009), we do not have data on the respondent's place of residence at the age of 15-19 or on the respondent's parents that would have allowed us to create an instrument for early occupation choice. ${ }^{10}$ Model 4 accounts for the heterogeneity of the effects of RTI by age and therefore provides no average effect that could
be directly compared with the estimates of models 1-3 presented in Table 7 .
} 
Table 7. The effect of the routine task intensity (RTI) on the probability of being unemployed, the estimated odds ratios from logit models 1-3

\begin{tabular}{|c|c|c|c|c|c|c|c|c|c|c|c|c|}
\hline & Austria & Belgium & Czechia & Denmark & Estonia & Germany & Greece & Hungary & Poland & Spain & Sweden & $\begin{array}{c}\text { United } \\
\text { Kingdom }\end{array}$ \\
\hline \multicolumn{13}{|c|}{ Model 1} \\
\hline RTI & $\begin{array}{c}1.94^{\star \star \star} \\
(0.00)\end{array}$ & $\begin{array}{c}2.13^{\star \star \star} \\
(0.00)\end{array}$ & $\begin{array}{c}1.96 * \star \star \\
(0.00)\end{array}$ & $\begin{array}{c}1.77^{\star \star \star} \\
(0.00)\end{array}$ & $\begin{array}{c}2.00^{\star \star \star \star} \\
(0.00)\end{array}$ & $\begin{array}{c}2.08^{\star \star \star} \\
(0.00)\end{array}$ & $\begin{array}{c}1.86^{\star \star \star} \\
(0.01)\end{array}$ & $\begin{array}{c}2.48^{\star \star \star} \\
(0.00)\end{array}$ & $\begin{array}{c}2.42^{\star \star \star} \\
(0.00)\end{array}$ & $\begin{array}{c}1.45^{\star \star \star} \\
(0.01)\end{array}$ & $\begin{array}{c}1.96 * \star \star \\
(0.00)\end{array}$ & $\begin{array}{c}2.55^{\star \star \star} \\
(0.00)\end{array}$ \\
\hline $\begin{array}{c}\text { RTI * } \\
\text { period } \\
(2013-2015)\end{array}$ & $\begin{array}{c}1.03 \\
(0.87)\end{array}$ & $\begin{array}{c}0.98 \\
(0.89)\end{array}$ & $\begin{array}{c}1.10 \\
(0.24)\end{array}$ & $\begin{array}{c}1.17 \\
(0.21)\end{array}$ & $\begin{array}{c}1.06 \\
(0.67)\end{array}$ & $\begin{array}{c}1.03 \\
(0.84)\end{array}$ & $\begin{array}{c}1.13 \\
(0.67)\end{array}$ & $\begin{array}{c}0.98 \\
(0.86)\end{array}$ & $\begin{array}{c}0.88 \\
(0.57)\end{array}$ & $\begin{array}{l}1.63^{\star \star \star} \\
(0.01)\end{array}$ & $\begin{array}{l}1.25^{\star} \\
(0.06)\end{array}$ & $\begin{array}{c}1.09 \\
(0.40)\end{array}$ \\
\hline \multicolumn{13}{|c|}{ Model 2} \\
\hline RTI & $\begin{array}{c}1.60 \star \star \star \\
(0.00)\end{array}$ & $\begin{array}{l}1.31^{\star \star} \\
(0.03)\end{array}$ & $\begin{array}{c}1.47^{\star \star \star} \\
(0.00)\end{array}$ & $\begin{array}{c}1.67^{\star \star \star} \\
(0.00)\end{array}$ & $\begin{array}{c}1.65^{\star \star \star} \\
(0.00)\end{array}$ & $\begin{array}{c}1.76^{\star \star \star} \\
(0.00)\end{array}$ & $\begin{array}{l}1.60 * \\
(0.10)\end{array}$ & $\begin{array}{c}1.75^{\star \star \star} \\
(0.00)\end{array}$ & $\begin{array}{c}2.02^{\star \star \star} \\
(0.00)\end{array}$ & $\begin{array}{c}1.07 \\
(0.62)\end{array}$ & $\begin{array}{c}1.53^{\star \star \star *} \\
(0.00)\end{array}$ & $\begin{array}{c}1.99 \star \star \star \\
(0.00)\end{array}$ \\
\hline $\begin{array}{c}\text { RTI* } \\
\text { period } \\
(2013-2015)\end{array}$ & $\begin{array}{c}1.06 \\
(0.68)\end{array}$ & $\begin{array}{c}1.02 \\
(0.89)\end{array}$ & $\begin{array}{c}1.05 \\
(0.57)\end{array}$ & $\begin{array}{c}1.17 \\
(0.21)\end{array}$ & $\begin{array}{c}1.06 \\
(0.61)\end{array}$ & $\begin{array}{c}1.00 \\
(0.98)\end{array}$ & $\begin{array}{c}1.08 \\
(0.81)\end{array}$ & $\begin{array}{c}0.90 \\
(0.36)\end{array}$ & $\begin{array}{c}0.79 \\
(0.25)\end{array}$ & $\begin{array}{l}1.64^{\star \star \star} \\
(0.00)\end{array}$ & $\begin{array}{l}1.27 \star \star \\
(0.03)\end{array}$ & $\begin{array}{c}1.03 \\
(0.74)\end{array}$ \\
\hline \multicolumn{13}{|c|}{ Model 3} \\
\hline RTI & $\begin{array}{c}1.64^{\star \star \star} \\
(0.00)\end{array}$ & $\begin{array}{c}1.43^{\star \star \star} \\
(0.00)\end{array}$ & $\begin{array}{l}1.4^{\star \star \star} \\
(0.00)\end{array}$ & $\begin{array}{c}1.67 * \star \star \\
(0.00)\end{array}$ & $\begin{array}{c}1.65^{\star \star \star} \\
(0.00)\end{array}$ & $\begin{array}{c}1.77^{\star \star \star} \\
(0.00)\end{array}$ & $\begin{array}{c}1.59 \\
(0.10)\end{array}$ & $\begin{array}{c}1.74^{\star \star \star} \\
(0.00)\end{array}$ & $\begin{array}{c}2.02^{\star \star \star} \\
(0.00)\end{array}$ & $\begin{array}{c}1.12 \\
(0.36)\end{array}$ & $\begin{array}{c}1.54^{\star \star \star} \\
(0.00)\end{array}$ & $\begin{array}{c}1.99 \star \star \star \\
(0.00)\end{array}$ \\
\hline $\begin{array}{c}\text { RTI * } \\
\text { period } \\
(2013-2015)\end{array}$ & $\begin{array}{c}1.09 \\
(0.05)\end{array}$ & $\begin{array}{c}0.97 \\
(0.32)\end{array}$ & $\begin{array}{c}1.06 \\
(0.00)\end{array}$ & $\begin{array}{c}1.20 \\
(0.59)\end{array}$ & $\begin{array}{c}1.06 \\
(0.00)\end{array}$ & $\begin{array}{c}1.03 \\
(0.00)\end{array}$ & $\begin{array}{c}1.07 \\
(0.00)\end{array}$ & $\begin{array}{c}0.91 \\
(0.06)\end{array}$ & $\begin{array}{c}0.79 \\
(0.89)\end{array}$ & $\begin{array}{l}1.61^{\star \star \star} \\
(0.08)\end{array}$ & $\begin{array}{l}1.27^{\star \star} \\
(0.01)\end{array}$ & $\begin{array}{c}1.03 \\
(0.00)\end{array}$ \\
\hline
\end{tabular}

Note: Model 1 - explanatory variables: RTI, time dummy (ref. 1998-2000). Model 2 - explanatory variables: RTI, time dummy (ref. 19982000) and personal characteristics (age, gender, marital status, education level). Model 3 - explanatory variables: RTI, time dummy (ref. 1998-2000), personal characteristics (age, gender, marital status, education level) and regional controls (industry shares at the point in time when the worker was aged 17 or the earliest available shares, and Bartik (1991) local labour demand shocks). The standard errors are clustered at the occupation level. Only the results for the RTI are presented. The results for the other explanatory variables are available upon request. Due to data availability, the reference period is 1999-2001 for Germany and the United Kingdom and is 2003-2005 for Sweden. P-value in parentheses. $* * * p<0.01, * * p<0.05, * p<0.1$.

Source: Own estimations based on EU-LFS, 0*NET, and Cambridge Econometrics European Regional Data.

Allowing for heterogeneous effects of RTI by age (model 4), we find that in several countries the relationship between the routine intensity and the probability of unemployment is declining with age. We reach this conclusion by calculating country-specific, aggregate marginal effects of the RTI on the unemployment probability for each 10-year age group in both periods, while holding other variables at their age-specific means (Figure 2). The marginal effects of RTI on unemployment risk were declining with age particularly in Belgium (both periods), Germany (2013-2015), Hungary (2013-2015) and the United Kingdom (both periods) where the marginal effects of RTI among 15-24 year-olds and/or 25-34 year-olds were significantly higher than among 45-54 year-olds and 55-64 year-olds (the 95\% confidence intervals of marginal effects among the latter and the former age groups don't overlap). Belgium, Germany and the UK belonged to the countries where the overall decline of the intensity of routine tasks was the highest, while Hungary was the only CEE countries where the intensity of routine cognitive tasks decreased. In Austria (2013-2015), Denmark (20132015), Estonia, Poland (1998-2000) and Sweden, a similar negative pattern is visible but the differences between young and older workers are not significant. On the other hand, in Greece and Spain, two countries where the routine intensive occupations were not ageing faster (Table 3), the marginal effects of RTI by age are flat or even slightly increasing, especially in Greece in 2013-2015. 
Figure 2. The marginal effects of the routine task intensity (RTI) on the unemployment risk, by age, calculated from the country-specific logit regressions with heterogeneous effects of the RTI by age, 1998-2000* and 2013-2015.
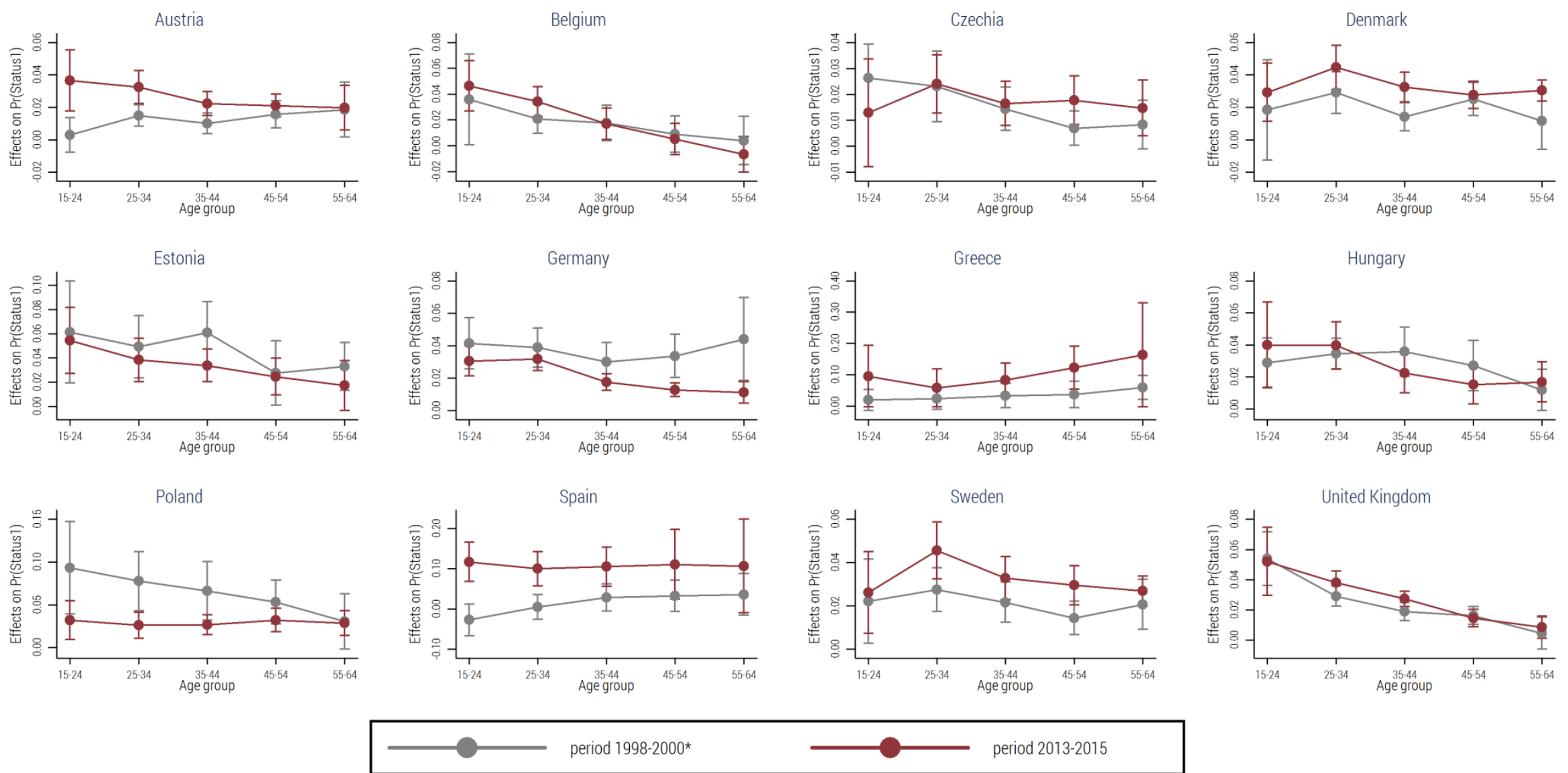

Note: explanatory variables: RTI, time dummy (ref. 1998-2000), personal characteristics (age, gender, marital status, education) and regional controls (regional industry shares when the worker was aged 15-19 or the earliest available shares, and Bartik (1991) local labour demand shocks), and interactions between the RTI and age. The standard errors clustered at the occupation level. All estimation results are in Table A6 in the appendix. Confidence intervals at $95 \%$.

*Due to data availability, 1999-2007 for Germany and the United Kingdom, 2003-2005 for Sweden.

Source: Own estimations based on EU-LFS, O*NET, and Cambridge Econometrics European Regional Data. 
Importantly, the marginal effects of RTI increased over time in the majority of countries studied, most notably in Greece and Spain. In Greece, these were the oldest workers who recorded the highest marginal effect of RTI equal to 16.3 pp. in 2013-2015 (5.9 pp. in 1998-2000). At the same time, the effect among workers aged 15-24 amounted to 9.6 pp. in 2013-2015 (2.0 pp. in 1998-2000). In Spain the marginal effects of RTI increased for all age groups. In 1998-2000, these effects ranged from $-2.8 \mathrm{pp}$. among the 15-24 year-olds to $3.6 \mathrm{pp}$. among the 55-64 year-olds. In 2013-2015, they ranged from $10.0 \mathrm{pp}$. among the 25-34 year-olds to $11.7 \mathrm{pp}$. among the 1524 year-olds. Estonia, Germany and Poland where the only countries where the marginal effects of RTI declined over time. All these countries recorded a secular improvement in labour market situations between the late 1990s and the middle 2010s.

The age differences in marginal effects of routine intensity on the unemployment risk seem associated with the differences in age-specific distributions of other characteristics, such as education level attained. The age specific odds-ratios of RTI differ significantly from the reference group (25-34 years) only in few cases (see Table A6 in appendix). In Germany and the United Kingdom the association between the RTI and unemployment risk was significantly smaller among the older workers than among workers aged 25-34. In Austria (in 1998-2000) and Sweden (in both periods) the youngest workers. recorded a significantly lower effect of RTI than the prime-aged workers. In Spain, the strength of this relationship was increasing with age.

\section{Conclusions and policy implications}

In this paper, we analysed changes in the task composition of jobs in 12 European countries (Austria, Belgium, Czechia, Denmark, Estonia, Germany, Greece, Hungary, Poland, Spain, Sweden, and the United Kingdom) with a focus on the age differences in the content of jobs and the related unemployment risks between 1998 and 2015. We found that shifts in the task composition varied between various age groups. Compared to workers aged between 25 and 44 years, workers aged between 15 and 24 years and workers aged between 45 and 64 years experienced less a pronounced shift away from routine cognitive tasks and manual tasks and towards non-routine cognitive tasks. In the majority of the countries studied, the age structures of the occupations with relatively high routine intensities of tasks in 1998 had aged more rapidly by 2010 than the occupations with the lower routine intensities. This finding was in turn related to a stronger relative decline in the share of young workers (aged 15-24) in the more routine-intensive occupations, and in the stronger increase in the share of older workers (aged 45-64). On the other hand, the age structures of the occupations with relatively high non-routine cognitive content in 1998 had aged more slowly by 2010.

The previous literature (Autor et al.; 2003, Michaels et al.; 2014, Goos et al.; 2014) showed that the hollowingout of middle-skilled, routine jobs is likely to be driven by demand-side factors. Consequently, these factors may influence the unemployment risk of routine workers. Indeed, we found that in six out of the 12 countries we studied the more routine intensive an occupation was in 1998, the greater the increase in the share of unemployed workers in this occupation was by 2010. At an individual level, a higher routine intensity was significantly related to a higher probability of unemployment in all of the countries studied, both in the late 1990s and in the 2010s. In most of the countries, this effect was strongest for the younger workers (aged 1524, but also those aged 25-34) than for the older workers. Our findings is consistent with Dauth et al. (2017) 
results for Germany which showed that robots affected the composition of employment and reduced employment of young workers in routine occupations. Greece and Spain stand out as two countries were routine intensive occupations were not ageing faster and the unemployment risks related to the routine intensity were the highest among the older workers.

Our findings have potential policy implications. On the one hand, as older workers have so far been less affected by occupational changes than younger workers, and the age structures of routine-intensive occupations are ageing faster, older workers may be disproportionately affected if the shift away from routine work intensifies in the future. Life-long learning and on-the-job training are needed to address the challenges that older workers face, especially considering the European-wide gap in ICT skills between older and younger workers (as shown in the PIAAC survey). On the other hand, educational systems should be adapted to foster the development of the skills required to perform non-routine tasks, because young workers who enter more routine-intensive occupations face a relatively high unemployment risk, which has been increasing in recent years. Even if this effect can partly reflect the sorting of individuals with less human capital into more routineintensive occupations, it is still important that educational systems seek to impart the skills that will enable individuals to take non-routine jobs, as the failure to train people in these higher level skills will exacerbate inequalities in labour markets outcomes.

In terms of directions for future research, we think that analyses of wage differences, conditional on age and tasks performed by workers, could shed light on the question of how the changes in task structures affect labour market inequalities. Unfortunately, the EU-LFS do not provide precise and comprehensive data on wages. Accounting for the heterogeneity of tasks within occupations is also an interesting avenue for future research. However, the surveys that collect such data, like the PIAAC for the OECD countries and the STEP for the developing countries, offer only one dataset per country. Thus, the analysis of changes over time will not be possible until the second waves of these surveys are completed.

\section{References}

Acemoglu, D., Autor, D. H. (2011). Skills, Tasks and Technologies: Implications for Employment and Earnings. In: Card, D. and Ashenfelter, O. (eds). Handbook of Labor Economics. Amsterdam: Elsevier, pp. 1043-1171.

Acemoglu, D., Restrepo, P. (2017). Secular Stagnation? The Effect of Aging on Economic Growth in the Age of Automation. NBER Working Paper No. 23077, National Bureau of Economic Research, Inc.

Aedo, C., Hentschel, J., Moreno, M., Luque, J. (2013). From occupations to embedded skills: a cross-country comparison. World Bank Policy Research Working Paper.

Arias, O.S., Sánchez-Páramo, C., Dávalos, M.E., Santos, I., Tiongson, E.R., Gruen, C., de Andrade Falcão, N., Saiovici, G., Cancho, C.A. (2014). Back to work: growing with jobs in Eastern Europe and Central Asia, Europe and Central Asia reports. Washington, DC.: The World Bank.

Aubert, P., Caroli, E., Roger, M. (2006). New Technologies, Organisation and Age: Firm-Level Evidence. The Economic Journal, 116 (509): F73-F93. 
Autor, D. H., Katz, L. F., Kearney, M.S. (2006). The Polarization of the U.S. Labor Market. American Economic Review Papers and Proceedings 96, 2.

Autor, D. H., Levy, F., Murnane, R. (2003). The Skill Content of Recent Technological Change: An Empirical Exploration. Quarterly Journal of Economics 118, 4.

Autor, D. H., Dorn, D. (2009). This Job is "Getting Old": Measuring Changes in Job Opportunities using Occupational Age Structure. American Economic Review: Papers \& Proceedings, 99:2, 45-51.

Autor, D. H., Dorn, D., Hanson, G. H. (2015). Untangling Trade and Technology: Evidence from Local Labour Markets. Economic Journal, Royal Economic Society, vol. 0 (584), 621-646, 05.

Autor, D. H., Price, B.M. (2013). The Changing Task Composition of the US Labor Market: An Update of Autor, Levy and Murnane. MIT Monograph.

Bartik, T. J. (1991). Who Benefits from State and Local Economic Development Policies?, Books from Upjohn Press, W.E. Upjohn Institute for Employment Research, number wbsle, 06.

Bosch, N., ter Weel, B. (2013). Labour-Market Outcomes of Older Workers in the Netherlands: Measuring Job Prospects Using the Occupational Age Structure. De Economist, 161 (2): 199-218.

Brynjolfsson, E., McAfee, A. (2014). The Second Machine Age: Work Progress, and Prosperity in a Time of Brilliant Technologies. New York: W. W. Norton \& Company.

Cedefop (2013). Quantifying skill needs in Europe occupational skills profiles: methodology and application. Thessaloniki: Cedefop.

Central Statistical Office of Poland. Labour Force Survey data, annual data 1998-2014. Warsaw: GUS.

Cortes, G.M. (2016). Where Have the Middle-Wage Workers Gone? A Study of Polarization Using Panel Data. Journal of Labor Economics, 34(1), 63-105.

Dauth W., Findeisen S., Südekum J., Wößner N. (2017). German Robots - The Impact of Industrial Robots on Workers. CEPR Discussion Paper 12306

de la Rica, S., Gortazar, L. (2016). Differences in Job De-Routinization in OECD Countries: Evidence from PIAAC, IZA Discussion Paper No. 9736

Deming, D. (2015). The Growing Importance of Social Skills in the Labor Market, NBER Working Paper No. 21473, National Bureau of Economic Research, Inc.

Desjardins, R., Warnke, A. J. (2012). Ageing and Skills: A Review and Analysis of Skill; Gain and Skill Loss Over the Lifespan and Over Time, OECD Education Working Papers, No. 72.

Dicarlo, E., Bello, S. L., Monroy-Taborda, S., Oviedo A. M., Sanchez-Puerta, M. L., Santos, I. (2016). The Skill Content of Occupations across Low and Middle Income Countries: Evidence from Harmonized Data. IZA Discussion Paper No. 10224.

European Commission, Eurostat (2016). European Union Labour Force Survey 1998-2014. Brussels: European Commission, Eurostat. 
Fletcher J., Sindelar J. (2009). Estimating Causal Effects of Early Occupational Choice on Later Health: Evidence Using the PSID, NBER Working Papers 15256, National Bureau of Economic Research, Inc.

Gimpelson, V., Kapeliushnikov, R. (2016). Polarization or Upgrading? Evolution of Employment in Transitionary Russia. Russian Journal of Economics 2 (2), 192-218.

Goos, M., Manning, A., Salomons, A. (2009). Job Polarization in Europe. American Economic Review: Papers \& Proceedings 99:2, 58-63.

Goos, M., Manning, A., Salomons, A. (2014). Explaining Job Polarization: Routine-Biased Technological Change and Offshoring. American Economic Review 104, 2509-2526.

Graetz, G., Michaels, G. (2015). Robots at Work, CEP Discussion Papers dp1335, Centre for Economic Performance, LSE.

Handel, M.J. (2012) Trends in Job Skill Demands in OECD Countries, OECD Social, Employment and Migration Working Papers No. 143.

Hardy, W., Keister, R., Lewandowski, P. (2016). Technology or upskilling? Trends in the task composition of jobs in Central and Eastern Europe. IBS Working Paper 01/2016.

Hummels D., Munch J., Xiang C. (2016). Offshoring and Labor Markets, NBER Working Papers No. 22041, National Bureau of Economic Research, Inc.

Marcolin, L., Miroudot, S., Squicciarini, M. (2016). Routine jobs, employment and technological innovation in global value chains. OECD Science, Technology and Industry Working Papers, No. 2016/01, OECD Publishing, Paris.

Michaels, G., Natraj, A., Van Reenen, J. (2014). Has ICT polarized skill demand? Evidence from eleven countries over twenty-five years. Review of Economics and Statistics 96, 60-77.

Morris, M. G., Venkatesh, V. (2000). Age differences in technology adoption decisions: implications for a changing work force. Personnel Psychology 53.

OECD (2013). OECD Skills Outlook 2013, Paris.

OECD. (2017). Pensions at a Glance 2017. Paris: Organisation for Economic Co-operation and Development.

Oesch D. (2013). Occupational Change in Europe. How Technology and Education Transform the Job Structure. Oxford University Press.

Salvatori, A. (2015). The Anatomy of Job Polarisation in the UK. IZA Discussion Papers 9193.

Spitz-Oener, A. (2006). Technical Change, Job Tasks, and Rising Educational Demands: Looking outside the Wage Structure. Journal of Labor Economics 24, 235-270.

Tempest, S., Coupland, C. (2016). Lost in time and space: temporal and spatial challenges facing older workers in a global economy from a career capital perspective. The International Journal of Human Resource Management, 1-25. 


\title{
Appendix
}

\begin{abstract}
A1. Data
The move from the ISCO-88 (COM) to the ISCO-08 classification led to shifts in the occupational time-series, since the classifications are not entirely comparable. In particular, the non-routine cognitive task intensities of farming occupations are much higher in the ISCO-88 than in the ISCO-08. However, farming jobs are typically associated with routine and manual tasks (Arias et al., 2014), and involve relatively few non-routine cognitive tasks (Acemoglu \& Autor, 2011). We therefore assumed that the ISCO-08 classification is more precise, and replaced the values of task items for some farming occupations in the ISCO-88 data with the task items in the ISC0-88 data. In each country separately, we selected at least three occupations that jointly represented at least $80 \%$ of the employment in agriculture (starting from the occupations with the largest shares) in 1998. For those ISCO-88 occupations, we matched the task items from the relevant occupations in the ISCO-08 (an average if more than one was matched) using the crosswalk provided by ILO. ${ }^{11}$ Table A1 shows which occupations were updated in particular countries in order to ensure the consistency of the task data.

Corrections were also needed in the coding of occupations in the wholesale and retail trade sector. The ISCO08 distinguishes between salespersons and supervisors within the group 522, whereas the ISCO-88 did not. This occupational group accounts for a large share of employment in wholesale and retail trade, and thus significantly influences the task composition in this sector. Since the EU-LFS occupational data are not coded at a 4-digit level, large shifts emerged in the intensity of routine cognitive tasks between 2010 and 2011 (the time of the transition to the ISCO-08). We therefore excluded occupations 5222 (shop supervisors) and 5221 (shop keepers) from our 0*NET data; and from 2011 onwards, we assigned the mean task items of occupational group 5223 (shop sales assistants) to the occupational group 522 (shop salesperson). We found no other substantial differences in the ways in which occupations were coded in the ISCO-88 and the ISCO-08, but there are some breaks in the data that may be due to changes in country-specific classifications of occupations that are mapped into the ISCO in the EU-LFS.
\end{abstract}

\footnotetext{
${ }^{11}$ http://www.lo.org/public/english/bureau/stat/isco/isco08/ [accessed: 2017-01-30]
} 


\section{A2. Tables \& Figures}

Table A1. List of ISCO-88 occupations comprising at least $80 \%$ of agriculture in 1998 , subsequently updated with matched ISCO-08 values, by country

\begin{tabular}{|l|l|}
\hline Country & ISCO-88 occupations \\
\hline Austria & $611,612,613$ \\
\hline Belgium & $131,611,612$ \\
\hline Czechia & $321,343,611,612,613,614,723,832,833,921$ \\
\hline Denmark & $611,612,613,921$ \\
\hline Estonia & $321,343,612,613,614,615,832,833,834,915,921$ \\
\hline Germany & $321,610,611,612,614$ \\
\hline Greece & $611,612,613$ \\
\hline Hungary & $412,611,612,613,614,722,723,832,833,914,921,932$ \\
\hline Poland & 6111,6131 (KZiS; the classification was subsequently collapsed to the 3-digit level) \\
\hline Spain & $611,613,921$ \\
\hline Sweden & $611,612,613,614,833$ \\
\hline United Kingdom & $122,131,611,613,615,833,921$ \\
\hline \multicolumn{1}{|c|}{ Note: The matched occupations from the ISCO-08 come from the } \\
\hline
\end{tabular}

http://www.ilo.org/public/english/bureau/stat/isco/isco08/[accessed: 2017-01-30]

Source: Own elaboration based on the EU-LFS data.

Table A2. Occupational and sectoral data issues (missing data or country-specific coding), by country

\begin{tabular}{|l|l|}
\hline Country & Description \\
\hline Germany & The data for 1998 do not contain information on the last occupation for the unemployed. \\
\hline Poland & $\begin{array}{l}\text { We used Polish LFS data instead of the EU-LFS datasets for improved accuracy. Due to national changes in } \\
\text { classification, we rescaled the data near the breaks in the Polish classification of occupations (KZiS) in 2003, 2005 } \\
\text { and } 2011 \text { (see Hardy et al., 2015 for more details on KZiS changes). }\end{array}$ \\
\hline Sweden & $\begin{array}{l}\text { There is no ISCO-88 information for previous occupations before 2000 or in } 2001 \text { or 2002. There is no NACE v1 } \\
\text { information for previous industries before 2000 or in 2001, 2002, or 2008. The NACE v2 covers the year 2008. }\end{array}$ \\
\hline $\begin{array}{l}\text { United } \\
\text { Kingdom }\end{array}$ & $\begin{array}{l}\text { Due to national changes in classifications, we rescaled the data near the break in the classification of occupations (the } \\
\text { transition to the SOC-00) in 2001. The data for } 1998 \text { do not contain information on the last occupation of unemployed } \\
\text { individuals. }\end{array}$ \\
\hline
\end{tabular}

Source: Own elaboration based on the EU-LFS data.

Table A3. Occupational data non-response rate, by country

\begin{tabular}{|c|c|}
\hline & The share of sample with missing occupational code \\
\hline Austria & 1.1 \\
\hline Belgium & 1.1 \\
\hline Czechia & 1.3 \\
\hline Denmark & 0.3 \\
\hline Estonia & 0.7 \\
\hline Germany & 1.2 \\
\hline Greece & 1.7 \\
\hline Hungary & 0.7 \\
\hline Poland & 2.0 \\
\hline Spain & 1.5 \\
\hline Sweden & 0.5 \\
\hline United Kingdom & 0.8 \\
\hline
\end{tabular}

Source: Own elaboration based on the EU-LFS data. 
Table A4. Difference in routine and non-routine employment rates among 10-year age groups between 1998-200 and 2013-2015 by country, in pp.

\begin{tabular}{|c|c|c|c|c|c|c|c|c|c|c|c|c|c|c|c|}
\hline & \multicolumn{5}{|c|}{ Non-routine workers } & \multicolumn{5}{|c|}{ Routine workers } & \multicolumn{5}{|c|}{ Other workers } \\
\hline & $15-24$ & $25-34$ & $35-44$ & $45-54$ & $55-64$ & $15-24$ & $25-34$ & $35-44$ & $45-54$ & $55-64$ & $15-24$ & $25-34$ & $35-44$ & $45-54$ & $55-64$ \\
\hline Austria & -1.09 & 2.05 & 1.96 & 2.72 & 4.04 & -9.17 & -7.21 & -5.38 & -3.61 & 2.47 & 9.47 & 4.86 & 5.39 & 8.60 & 10.19 \\
\hline Belgium & 0.89 & 7.36 & 7.75 & 6.59 & 7.13 & -3.28 & -6.65 & -4.02 & 0.21 & 2.80 & -1.56 & -4.40 & -1.45 & 3.79 & 9.07 \\
\hline Czechia & -1.27 & 5.05 & 3.19 & 5.86 & 4.01 & -3.85 & -6.53 & -2.53 & -1.33 & 3.26 & -5.32 & 0.38 & 1.34 & 2.13 & 7.62 \\
\hline Germany & -0.01 & 6.53 & 5.10 & 1.30 & 7.03 & -4.84 & -7.14 & -6.01 & -3.61 & 2.78 & 7.64 & 11.04 & 11.09 & 9.03 & 17.99 \\
\hline Denmark & 1.72 & -2.57 & 0.26 & -3.76 & 0.93 & 3.41 & -3.94 & -7.22 & -3.50 & -1.62 & -15.83 & 3.36 & 4.72 & 8.61 & 12.33 \\
\hline Estonia & -0.09 & -0.42 & 4.21 & -0.02 & 4.14 & -2.57 & -4.82 & -2.48 & -0.55 & 4.48 & 5.04 & 7.48 & 2.04 & 3.16 & 7.53 \\
\hline Greece & -1.69 & -4.86 & -6.08 & -3.17 & -2.20 & -5.88 & -8.71 & -9.20 & -7.80 & -3.19 & -5.74 & 3.16 & 5.99 & 8.90 & 1.48 \\
\hline Hungary & -2.00 & 4.16 & 2.77 & 1.42 & 4.26 & -4.58 & -3.13 & 0.26 & 4.73 & 6.87 & -4.43 & 3.04 & 3.42 & 4.79 & 11.66 \\
\hline Poland & 0.16 & 6.29 & 10.58 & 3.35 & 5.16 & -1.35 & -6.22 & -1.35 & 2.42 & 6.10 & -1.86 & -4.07 & -4.54 & -4.83 & 4.32 \\
\hline Spain & -0.27 & 0.37 & 0.22 & -0.12 & 2.46 & -7.64 & -4.81 & -2.40 & -0.65 & 1.75 & -2.94 & 1.53 & 4.20 & 6.17 & 4.82 \\
\hline Sweden & 0.65 & 0.69 & 4.85 & -0.23 & 3.01 & 0.42 & -7.76 & -9.31 & -6.66 & -4.66 & 6.64 & 13.07 & 9.39 & 11.14 & 11.77 \\
\hline $\begin{array}{c}\text { United } \\
\text { Kingdom }\end{array}$ & 1.22 & 2.44 & 3.05 & 2.21 & 5.72 & -9.96 & $\begin{array}{c}- \\
11.33\end{array}$ & $\begin{array}{c}- \\
13.69\end{array}$ & $\begin{array}{c}- \\
11.97\end{array}$ & -7.96 & 0.85 & 9.51 & 10.48 & 13.35 & 12.91 \\
\hline
\end{tabular}

Source: Own calculations based on EU-LFS and O*NET data.

Table A5. The relationship between the routine (RTI), non-routine cognitive analytical (NRCA) and non-routine cognitive personal (NRCP) intensity in 1998, and the changes in the mean ages of workers and change in the share of workers aged 15-24, 25-44, 45-64 in occupations between 1998 and 2015. Pooled regressions at the 1-digit occupation level with country dummies

\begin{tabular}{|c|c|c|c|c|c|c|}
\hline $\begin{array}{c}\text { Explanatory variable } \\
\text { of interest }\end{array}$ & RTI & RTI & RTI & RTI & NRCA & NRCP \\
\hline Explained variable & $\Delta$ age & $\Delta 15-24$ & $\Delta 25-44$ & $\Delta 45-64$ & $\Delta$ age & $\Delta$ age \\
\hline $\begin{array}{c}\text { Coefficient of } \\
\text { interest }\end{array}$ & $0.83^{\star \star \star}$ & $-0.02^{\star \star \star}$ & -0.01 & $0.03^{\star \star \star}$ & $-0.53^{\star \star \star}$ & $-0.35^{\star \star \star}$ \\
\hline \multirow{2}{*}{$\Delta$ Share } & $(0.00)$ & $(0.00)$ & $(0.28)$ & $(0.00)$ & $(0.00)$ & $(0.00)$ \\
\hline \multirow{2}{*}{ Austria } & -0.02 & -0.00 & 0.00 & -0.00 & -0.01 & -0.03 \\
& $(0.45)$ & $(0.65)$ & $(0.21)$ & $(0.31)$ & $(0.65)$ & $(0.20)$ \\
\hline \multirow{2}{*}{ Belgium } & 0.47 & -0.01 & -0.00 & 0.01 & 0.42 & 0.38 \\
& $(0.38)$ & $(0.37)$ & $(0.91)$ & $(0.49)$ & $(0.41)$ & $(0.49)$ \\
\hline \multirow{2}{*}{ Czechia } & 0.40 & -0.01 & 0.01 & 0.00 & 0.37 & 0.45 \\
& $(0.45)$ & $(0.35)$ & $(0.71)$ & $(0.83)$ & $(0.47)$ & $(0.41)$ \\
\hline \multirow{2}{*}{ Denmark } & -0.17 & $-0.07^{\star \star \star}$ & $0.16^{\star \star \star}$ & $-0.09^{\star \star \star}$ & -0.19 & -0.09 \\
& $(0.75)$ & $(0.00)$ & $(0.00)$ & $(0.00)$ & $(0.72)$ & $(0.86)$ \\
\hline \multirow{2}{*}{ Estonia } & -0.25 & -0.00 & $0.04^{\star}$ & -0.03 & -0.36 & -0.26 \\
& $(0.64)$ & $(0.87)$ & $(0.10)$ & $(0.11)$ & $(0.49)$ & $(0.63)$ \\
\hline \multirow{2}{*}{ Spain } & $-1.19^{\star \star}$ & $-0.02^{\star}$ & $0.10^{\star \star \star}$ & $-0.08^{\star \star \star}$ & $-1.25^{\star \star}$ & $-1.16^{\star \star}$ \\
& $(0.03)$ & $(0.07)$ & $(0.00)$ & $(0.00)$ & $(0.02)$ & $(0.04)$ \\
\hline \multirow{2}{*}{ Greece } & $1.46^{\star \star \star}$ & $-0.07^{\star \star \star}$ & $0.07^{\star \star \star}$ & -0.00 & $1.27 \star \star$ & $1.40^{\star \star}$ \\
& $(0.01)$ & $(0.00)$ & $(0.00)$ & $(0.89)$ & $(0.02)$ & $(0.01)$ \\
\hline \multirow{2}{*}{ Hungary } & 0.83 & $-0.07 \star \star \star$ & $0.08^{\star \star \star}$ & -0.02 & 0.73 & 0.78 \\
& $(0.13)$ & $(0.00)$ & $(0.00)$ & $(0.40)$ & $(0.16)$ & $(0.16)$ \\
\hline \multirow{2}{*}{ Poland } & $0.95^{\star}$ & $-0.07^{\star \star \star}$ & $0.10^{\star \star \star}$ & -0.03 & $0.92^{\star}$ & 0.88 \\
& $(0.08)$ & $(0.00)$ & $(0.00)$ & $(0.14)$ & $(0.08)$ & $(0.11)$ \\
\hline & -0.31 & $-0.04^{\star \star \star}$ & $0.09^{\star \star \star}$ & $-0.05^{\star \star}$ & -0.50 & -0.31 \\
& $(0.57)$ & $(0.01)$ & $(0.00)$ & $(0.01)$ & $(0.34)$ & $(0.57)$ \\
\hline
\end{tabular}




\begin{tabular}{|c|c|c|c|c|c|c|}
\cline { 2 - 6 } Sweden & $-2.70^{\star \star \star}$ & 0.02 & $0.10^{\star \star \star}$ & $-0.12^{\star \star \star}$ & $\begin{array}{c}-2.89^{\star \star \star} \\
(0.00)\end{array}$ & $\begin{array}{c}-2.79^{\star \star \star} \\
(0.00)\end{array}$ \\
\hline \multirow{2}{*}{ United Kingdom } & $(0.00)$ & $(0.25)$ & $(0.00)$ & $-0.00)$ & -0.63 \\
& -0.61 & -0.01 & $0.06^{\star \star \star}$ & $-0.05^{\star \star}$ & -0.68 & $(0.19)$ \\
\hline \multirow{2}{*}{ Constant } & $(0.26)$ & $(0.40)$ & $(0.01)$ & $(0.02)$ & $0.25)$ \\
\hline \multirow{2}{*}{ R-squared } & $2.41^{\star \star \star}$ & 0.00 & $-0.12^{\star \star \star}$ & $0.12^{\star \star \star}$ & $4.38^{\star \star \star}$ & $3.74^{\star \star \star}$ \\
& $(0.00)$ & $(0.70)$ & $(0.00)$ & $(0.00)$ & $(0.00)$ & $(0.00)$ \\
\hline
\end{tabular}

Note: Each coefficient was estimated in a pooled regression at the 1-digit occupation level (108 observations) with country dummies. The change in the average age of workers, or a change in the share of workers aged 15-24, 25-44, 45-64 in a given occupation are the explained variables in particular regressions. The initial (1998) RTI or the initial (1998) intensity of nonroutine cognitive analytical (NRCA) or the initial (1998) intensity of non-routine cognitive personal (NRCP) tasks serve as variables of interest in particular regressions. All regression include the change in share of occupation in total employment as a control variable. P-value in parentheses. *** $p<0.01, * * p<0.05,{ }^{*} p<0.1$.

Source: Own estimations based on EU-LFS and O*NET data.

Table A6. Regional data available in EU-LFS, by country

\begin{tabular}{|c|c|c|}
\hline & $1998-2000^{*}$ & $2012-2014$ \\
\hline Austria & NUTS 1 & NUTS 1 \\
\hline Belgium & NUTS 2 & NUTS 2 \\
\hline Czechia & NUTS 2 & NUTS 2 \\
\hline Denmark & regional data missing & NUTS 2 \\
\hline Estonia & NUTS 2 & NUTS 1 \\
\hline Germany & regional data missing & NUTS 2 \\
\hline Greece & NUTS 2 & NUTS 2 \\
\hline Hungary & NUTS 2 & NUTS 2 \\
\hline Poland & NUTS 2 & NUTS 2 \\
\hline Spain & NUTS 2 & NUTS 2 \\
\hline Sweden & NUTS 2 & NUTS 1 \\
\hline United Kingdom & NUTS 1 & \\
\hline
\end{tabular}

Note*:Due to data availability, 1999-2001 for Germany and the United Kingdom, 2003-2005 for Sweden.

Source: Own elaboration based on the EU-LFS data.

Table A7. Logit estimation results - on being unemployed (0-employed), odds ratios (model 4)

\begin{tabular}{|c|c|c|c|c|c|c|c|c|c|c|c|c|}
\hline & Austria & Belgium & Czechia & Denmark & Estonia & Germany & Greece & Hungary & Poland & Spain & $\begin{array}{c}\text { Swede } \\
n\end{array}$ & $\begin{array}{c}\text { United } \\
\text { Kingdom }\end{array}$ \\
\hline $\mathrm{RTI}$ & $\begin{array}{l}1.98^{\star \star \star} \\
(0.00)\end{array}$ & $\begin{array}{l}1.49 \star \star \star \\
(0.00)\end{array}$ & $\begin{array}{l}1.5^{\star \star \star} \\
(0.00)\end{array}$ & $\begin{array}{l}1.88 \star \star \star \\
(0.00)\end{array}$ & $\begin{array}{l}1.74 \text { } \\
(0.00)\end{array}$ & $\begin{array}{l}2.1^{\star \star \star} \\
(0.00)\end{array}$ & $\begin{array}{l}1.32 \\
(0.18)\end{array}$ & $\begin{array}{l}1.7^{\star \star \star} \\
(0.00)\end{array}$ & $\begin{array}{c}2.07 \text { }(0.00) \\
(0.0\end{array}$ & $\begin{array}{c}1.04 \\
(0.75)\end{array}$ & 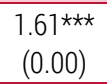 & $\begin{array}{c}2.37^{\star \star \star} \\
(0.00)\end{array}$ \\
\hline $\begin{array}{l}\text { Period(ref. } \\
\text { 1998-2000) }\end{array}$ & $\begin{array}{l}1.64^{\star \star \star} \\
(0.00)\end{array}$ & $\begin{array}{c}0.98 \\
(0.88)\end{array}$ & 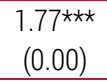 & $\begin{array}{l}1.19 \\
(0.35)\end{array}$ & $\begin{array}{l}0.59 \star \star \\
(0.04)\end{array}$ & $\begin{array}{l}0.6^{\star \star \star} \\
(0.00)\end{array}$ & $\begin{array}{c}4.18^{\star \star \star} \\
(0.00)\end{array}$ & $\begin{array}{c}0.95 \\
(0.63) \\
\end{array}$ & $\begin{array}{c}1.10 \\
(0.72)\end{array}$ & $\begin{array}{c}1.12 \\
(0.26)\end{array}$ & $\begin{array}{l}0.69 \star \star \\
(0.02)\end{array}$ & $\begin{array}{l}1.25^{\star} \\
(0.05)\end{array}$ \\
\hline period*RTI & $\begin{array}{c}0.93 \\
(0.72)\end{array}$ & $\begin{array}{l}1.15 \\
(0.3)\end{array}$ & $\begin{array}{c}1.09 \\
(0.53)\end{array}$ & $\begin{array}{c}1.12 \\
(0.54)\end{array}$ & $\begin{array}{c}1.07 \\
(0.73)\end{array}$ & $\begin{array}{c}1.04 \\
(0.78)\end{array}$ & $\begin{array}{l}1.01 \\
(0.98)\end{array}$ & $\begin{array}{c}1.16 \\
(0.24)\end{array}$ & $\begin{array}{l}0.69 \star \\
(0.09)\end{array}$ & $\begin{array}{l}1.59 \star \star \star \\
(0.00)\end{array}$ & $\begin{array}{l}1.41^{\star \star} \\
(0.02)\end{array}$ & $\begin{array}{c}1.15 \\
(0.24)\end{array}$ \\
\hline \multicolumn{13}{|c|}{ Age group (ref. 15-24) } \\
\hline $25-34$ & $\begin{array}{l}0.74^{\star} \\
(0.07)\end{array}$ & $\begin{array}{c}0.76 \\
(0.16) \\
\end{array}$ & $\begin{array}{l}0.73^{\star \star} \\
(0.03)\end{array}$ & $\begin{array}{c}0.96 \\
(0.83) \\
\end{array}$ & $\begin{array}{c}0.67 \\
(0.11) \\
\end{array}$ & $\begin{array}{c}0.43^{\star \star \star} \\
(0.00)\end{array}$ & $\begin{array}{l}0.71^{\star \star} \\
(0.02)\end{array}$ & $\begin{array}{c}0.86 \\
(0.14) \\
\end{array}$ & $\begin{array}{c}0.87 \\
(0.48) \\
\end{array}$ & $\begin{array}{c}1.13 \\
(0.16) \\
\end{array}$ & $\begin{array}{c}1.75^{\star \star \star} \\
(0.00)\end{array}$ & $\begin{array}{l}1.06 \\
(0.6) \\
\end{array}$ \\
\hline $35-44$ & $\begin{array}{l}1.60 \star \star \star \\
(0.00)\end{array}$ & $\begin{array}{c}0.98 \\
(0.89)\end{array}$ & $\begin{array}{l}0.8^{\star \star} \\
(0.03)\end{array}$ & $\begin{array}{c}0.85 \\
(0.39)\end{array}$ & $\begin{array}{l}1.38^{\star} \\
(0.1)\end{array}$ & $\begin{array}{l}1.44^{\star \star \star} \\
(0.00)\end{array}$ & $\begin{array}{l}0.63^{\star} \\
(0.06)\end{array}$ & $\begin{array}{c}0.87 \\
(0.21)\end{array}$ & $\begin{array}{c}0.87 \\
(0.16)\end{array}$ & 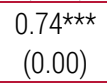 & $\begin{array}{c}0.78^{\star \star \star} \\
(0.00)\end{array}$ & $\begin{array}{c}1.04 \\
(0.56)\end{array}$ \\
\hline $45-54$ & $\begin{array}{c}2.11 * \star \star \\
(0.00)\end{array}$ & $\begin{array}{c}0.95 \\
(0.78) \\
\end{array}$ & $\begin{array}{c}0.72^{\star \star \star} \\
(0.01)\end{array}$ & $\begin{array}{l}1.01 \\
(0.98)\end{array}$ & $\begin{array}{c}1.28 \\
(0.21)\end{array}$ & $\begin{array}{l}1.77^{\star \star \star} \\
(0.00)\end{array}$ & $\begin{array}{l}0.57^{\star} \\
(0.06)\end{array}$ & $\begin{array}{c}0.66^{\star \star \star} \\
(0.01)\end{array}$ & $\begin{array}{c}0.72^{\star \star \star} \\
(0.01)\end{array}$ & $\begin{array}{c}0.58 * \star \star \\
(0.00)\end{array}$ & $\begin{array}{c}0.59 \star \star \star \\
(0.00)\end{array}$ & $\begin{array}{c}1.12 \\
(0.38)\end{array}$ \\
\hline $55-64$ & $\begin{array}{c}3.58^{\star * \star} \\
(0.00)\end{array}$ & $\begin{array}{c}0.76 \\
(0.38)\end{array}$ & $\begin{array}{l}0.62^{\star \star} \\
(0.03)\end{array}$ & $\begin{array}{l}1.45 \\
(0.12)\end{array}$ & $\begin{array}{l}0.60^{\star \star} \\
(0.02)\end{array}$ & $\begin{array}{c}3.52^{\star \star \star} \\
(0.00)\end{array}$ & $\begin{array}{l}0.35^{\star \star} \\
(0.02)\end{array}$ & $\begin{array}{l}0.56^{\star \star} \\
(0.02)\end{array}$ & $\begin{array}{c}0.71 \\
(0.23)\end{array}$ & $\begin{array}{l}0.64^{\star} \\
(0.09)\end{array}$ & $\begin{array}{l}0.75^{\star} \\
(0.08)\end{array}$ & $\begin{array}{c}1.75^{\star \star \star} \\
(0.00)\end{array}$ \\
\hline \multicolumn{13}{|c|}{ Age group*RTI (ref. 15-24*RTI) } \\
\hline
\end{tabular}




\begin{tabular}{|c|c|c|c|c|c|c|c|c|c|c|c|c|}
\hline $25-34$ & $\begin{array}{c}0.57^{\star \star \star} \\
(0.01)\end{array}$ & $\begin{array}{c}1.10 \\
(0.69)\end{array}$ & $\begin{array}{c}1.01 \\
(0.93)\end{array}$ & $\begin{array}{c}0.74 \\
(0.23)\end{array}$ & $\begin{array}{c}1.10 \\
(0.68)\end{array}$ & $\begin{array}{c}1.14 \\
(0.32) \\
\end{array}$ & $\begin{array}{c}0.97 \\
(0.82)\end{array}$ & $\begin{array}{c}0.89 \\
(0.26)\end{array}$ & $\begin{array}{c}0.97 \\
(0.84)\end{array}$ & $\begin{array}{l}0.81^{\star \star} \\
(0.04)\end{array}$ & $\begin{array}{c}0.77^{\star \star \star} \\
(0.01)\end{array}$ & $\begin{array}{c}1.07 \\
(0.55)\end{array}$ \\
\hline $35-44$ & $\begin{array}{c}0.83 \\
(0.27)\end{array}$ & $\begin{array}{c}1.00 \\
(0.99)\end{array}$ & $\begin{array}{c}0.93 \\
(0.47)\end{array}$ & $\begin{array}{l}0.83 \\
(0.3)\end{array}$ & $\begin{array}{c}1.01 \\
(0.95)\end{array}$ & $\begin{array}{c}0.82^{\star \star \star} \\
(0.00)\end{array}$ & $\begin{array}{c}1.34 \\
(0.25)\end{array}$ & $\begin{array}{l}1.11 \\
(0.4)\end{array}$ & $\begin{array}{l}0.99 \\
(0.9)\end{array}$ & $\begin{array}{l}1.27^{\star \star} \\
(0.03)\end{array}$ & $\begin{array}{c}1.02 \\
(0.84)\end{array}$ & $\begin{array}{l}0.84^{\star \star} \\
(0.03)\end{array}$ \\
\hline $45-54$ & $\begin{array}{c}0.88 \\
(0.52)\end{array}$ & $\begin{array}{c}0.84 \\
(0.35)\end{array}$ & $\begin{array}{l}0.80^{\star} \\
(0.08)\end{array}$ & $\begin{array}{l}1.03 \\
(0.9)\end{array}$ & $\begin{array}{c}0.77 \\
(0.21)\end{array}$ & $\begin{array}{l}0.81^{\star \star} \\
(0.03)\end{array}$ & $\begin{array}{c}1.45 \\
(0.23)\end{array}$ & $\begin{array}{c}1.09 \\
(0.62)\end{array}$ & $\begin{array}{c}0.95 \\
(0.67)\end{array}$ & $\begin{array}{l}1.37^{*} \\
(0.1)\end{array}$ & $\begin{array}{c}0.97 \\
(0.81)\end{array}$ & $\begin{array}{l}0.78 \text { ** } \\
(0.03)\end{array}$ \\
\hline $55-64$ & $\begin{array}{c}0.79 \\
(0.31)\end{array}$ & $\begin{array}{c}0.76 \\
(0.39) \\
\end{array}$ & $\begin{array}{c}0.88 \\
(0.52)\end{array}$ & $\begin{array}{c}0.69 \\
(0.15)\end{array}$ & $\begin{array}{c}1.01 \\
(0.97)\end{array}$ & $\begin{array}{l}0.72^{\star \star} \\
(0.03)\end{array}$ & $\begin{array}{l}2.35^{\star} \\
(0.05)\end{array}$ & $\begin{array}{c}0.85 \\
(0.51)\end{array}$ & $\begin{array}{c}0.77 \\
(0.35)\end{array}$ & $\begin{array}{l}1.36 \\
(0.2)\end{array}$ & $\begin{array}{c}1.01 \\
(0.94)\end{array}$ & $\begin{array}{c}0.49 \star \star \star \\
(0.00)\end{array}$ \\
\hline \multicolumn{13}{|c|}{ Age group * period 2013-2015 (ref. age group = 15-24) } \\
\hline $25-34$ & $\begin{array}{l}0.87 \\
(0.5)\end{array}$ & $\begin{array}{c}1.28 \\
(0.22) \\
\end{array}$ & $\begin{array}{c}1.22 \\
(0.35)\end{array}$ & $\begin{array}{c}0.91 \\
(0.62) \\
\end{array}$ & $\begin{array}{c}1.05 \\
(0.87)\end{array}$ & $\begin{array}{l}1.54 \text { *** } \\
(0.00)\end{array}$ & $\begin{array}{l}0.78 \\
(0.2)\end{array}$ & $\begin{array}{l}1.26 \\
(0.17) \\
\end{array}$ & $\begin{array}{c}1.05 \\
(0.82) \\
\end{array}$ & $\begin{array}{c}1.16 \\
(0.25)\end{array}$ & $\begin{array}{c}1.11 \\
(0.32)\end{array}$ & $\begin{array}{l}1.36^{\star} \\
(0.07)\end{array}$ \\
\hline $35-44$ & $\begin{array}{c}0.81 \\
(0.21)\end{array}$ & $\begin{array}{c}1.16 \\
(0.27)\end{array}$ & $\begin{array}{c}1.23 \\
(0.16)\end{array}$ & $\begin{array}{c}0.97 \\
(0.88)\end{array}$ & $\begin{array}{c}0.77 \\
(0.28)\end{array}$ & $\begin{array}{c}0.76^{\star \star \star} \\
(0.00)\end{array}$ & $\begin{array}{c}1.17 \\
(0.55)\end{array}$ & $\begin{array}{c}1.15 \\
(0.24) \\
\end{array}$ & $\begin{array}{l}0.81^{\star} \\
(0.07)\end{array}$ & $\begin{array}{c}1.14 \\
(0.22) \\
\end{array}$ & $\begin{array}{c}0.98 \\
(0.87) \\
\end{array}$ & $\begin{array}{c}0.95 \\
(0.66) \\
\end{array}$ \\
\hline $45-54$ & $\begin{array}{c}0.84 \\
(0.42)\end{array}$ & $\begin{array}{c}1.31 \\
(0.18)\end{array}$ & $\begin{array}{l}1.32^{\star} \\
(0.08)\end{array}$ & $\begin{array}{c}0.89 \\
(0.66)\end{array}$ & $\begin{array}{c}0.92 \\
(0.77)\end{array}$ & $\begin{array}{c}0.62^{\star \star \star} \\
(0.00)\end{array}$ & $\begin{array}{c}0.92 \\
(0.81)\end{array}$ & $\begin{array}{l}1.58 \star \star \star \\
(0.00)\end{array}$ & $\begin{array}{c}0.79 \\
(0.14)\end{array}$ & $\begin{array}{l}1.45^{\star \star} \\
(0.05)\end{array}$ & $\begin{array}{l}1.29 * \\
(0.07)\end{array}$ & $\begin{array}{c}1.09 \\
(0.56)\end{array}$ \\
\hline $55-64$ & $\begin{array}{l}0.61^{*} \\
(0.07)\end{array}$ & $\begin{array}{l}1.78 \\
(0.1)\end{array}$ & $\begin{array}{l}1.69 \star \star \\
(0.04)\end{array}$ & $\begin{array}{l}0.62^{\star} \\
(0.07)\end{array}$ & $\begin{array}{l}1.85^{\star} \\
(0.07)\end{array}$ & $\begin{array}{c}0.43 \star \star \star \\
(0.00)\end{array}$ & $\begin{array}{c}1.60 \\
(0.32)\end{array}$ & $\begin{array}{l}1.96^{\star \star} \\
(0.02)\end{array}$ & $\begin{array}{c}0.74 \\
(0.31)\end{array}$ & $\begin{array}{c}1.28 \\
(0.37)\end{array}$ & $\begin{array}{c}1.25 \\
(0.29)\end{array}$ & $\begin{array}{c}0.95 \\
(0.77)\end{array}$ \\
\hline \multicolumn{13}{|c|}{ Age group * RTI * period 2012-2014 (ref. age group $=15-24$ ) } \\
\hline $25-34$ & $\begin{array}{c}1.79 \star \star \star \\
(0.01)\end{array}$ & $\begin{array}{c}0.89 \\
(0.64)\end{array}$ & $\begin{array}{c}0.76 \\
(0.23)\end{array}$ & $\begin{array}{c}0.98 \\
(0.95)\end{array}$ & $\begin{array}{c}1.06 \\
(0.85)\end{array}$ & $\begin{array}{c}0.84 \\
(0.27)\end{array}$ & $\begin{array}{c}1.31 \\
(0.26)\end{array}$ & $\begin{array}{c}0.93 \\
(0.67)\end{array}$ & $\begin{array}{c}0.98 \\
(0.91)\end{array}$ & $\begin{array}{c}1.22 \\
(0.18)\end{array}$ & $\begin{array}{l}0.75^{\star \star} \\
(0.03)\end{array}$ & $\begin{array}{l}0.72^{\star} \\
(0.09)\end{array}$ \\
\hline $35-44$ & $\begin{array}{c}1.12 \\
(0.58)\end{array}$ & $\begin{array}{c}0.82 \\
(0.14)\end{array}$ & $\begin{array}{c}0.97 \\
(0.85)\end{array}$ & $\begin{array}{l}1.28 \\
(0.2)\end{array}$ & $\begin{array}{c}0.96 \\
(0.88)\end{array}$ & $\begin{array}{c}0.99 \\
(0.85)\end{array}$ & $\begin{array}{c}0.89 \\
(0.68)\end{array}$ & $\begin{array}{l}0.71^{\star \star} \\
(0.02)\end{array}$ & $\begin{array}{l}1.16 \\
(0.2)\end{array}$ & $\begin{array}{c}0.88 \\
(0.32)\end{array}$ & $\begin{array}{c}1.02 \\
(0.87)\end{array}$ & $\begin{array}{c}1.13 \\
(0.32)\end{array}$ \\
\hline $45-54$ & $\begin{array}{c}1.08 \\
(0.76)\end{array}$ & $\begin{array}{c}0.79 \\
(0.28) \\
\end{array}$ & $\begin{array}{c}1.16 \\
(0.39)\end{array}$ & $\begin{array}{c}0.89 \\
(0.63) \\
\end{array}$ & $\begin{array}{c}1.08 \\
(0.79) \\
\end{array}$ & $\begin{array}{l}0.92 \\
(0.5)\end{array}$ & $\begin{array}{l}1.09 \\
(0.8)\end{array}$ & $\begin{array}{c}0.63^{\star \star \star} \\
(0.01)\end{array}$ & $\begin{array}{l}1.33^{\star} \\
(0.07)\end{array}$ & $\begin{array}{l}0.84 \\
(0.5)\end{array}$ & $\begin{array}{c}0.99 \\
(0.95)\end{array}$ & $\begin{array}{c}0.79 \\
(0.12) \\
\end{array}$ \\
\hline $55-64$ & $\begin{array}{c}1.15 \\
(0.67)\end{array}$ & $\begin{array}{c}0.64 \\
(0.24)\end{array}$ & $\begin{array}{c}0.97 \\
(0.89)\end{array}$ & $\begin{array}{c}1.43 \\
(0.21)\end{array}$ & $\begin{array}{l}0.75 \\
(0.4)\end{array}$ & $\begin{array}{c}0.91 \\
(0.54)\end{array}$ & $\begin{array}{c}0.79 \\
(0.67)\end{array}$ & $\begin{array}{c}0.81 \\
(0.49)\end{array}$ & $\begin{array}{c}1.62 \\
(0.13)\end{array}$ & $\begin{array}{c}0.85 \\
(0.65)\end{array}$ & $\begin{array}{c}0.79 \\
(0.26)\end{array}$ & $\begin{array}{l}0.98 \\
(0.9)\end{array}$ \\
\hline \multicolumn{13}{|c|}{ Gender (ref. male) and marital status (ref. single) } \\
\hline Women & $\begin{array}{c}0.93 \\
(0.23)\end{array}$ & $\begin{array}{l}1.15^{\star} \\
(0.08)\end{array}$ & $\begin{array}{c}1.38 \star \star \star \\
(0.00)\end{array}$ & $\begin{array}{c}1.34^{\star * \star} \\
(0.00)\end{array}$ & $\begin{array}{c}0.90 \\
(0.23)\end{array}$ & $\begin{array}{c}0.95 \\
(0.35)\end{array}$ & $\begin{array}{l}1.27^{\star \star} \\
(0.02)\end{array}$ & $\begin{array}{l}0.91^{\star} \\
(0.1)\end{array}$ & 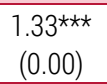 & $\begin{array}{l}1.23^{\star \star} \\
(0.05)\end{array}$ & $\begin{array}{l}0.91^{\star \star} \\
(0.04)\end{array}$ & $\begin{array}{c}0.77^{\star \star \star} \\
(0.00)\end{array}$ \\
\hline Married & $\begin{array}{c}0.57^{\star \star \star} \\
(0.00)\end{array}$ & $\begin{array}{c}0.64 \star \star \star \\
(0.00)\end{array}$ & $\begin{array}{c}0.55^{\star \star \star} \\
(0.00)\end{array}$ & $\begin{array}{c}0.58^{\star \star \star} \\
(0.00)\end{array}$ & $\begin{array}{c}0.73^{\star \star \star} \\
(0.00)\end{array}$ & $\begin{array}{c}0.61^{\star \star \star} \\
(0.00)\end{array}$ & $\begin{array}{c}0.60 \star \star \star \star \\
(0.00)\end{array}$ & $\begin{array}{c}0.67 \star \star \star \\
(0.00)\end{array}$ & $\begin{array}{l}0.6^{\star \star \star} \\
(0.00)\end{array}$ & $\begin{array}{c}0.71^{\star \star \star \star} \\
(0.00)\end{array}$ & $\begin{array}{c}0.75^{\star \star \star} \\
(0.00)\end{array}$ & $\begin{array}{c}0.46^{\star \star \star} \\
(0.00)\end{array}$ \\
\hline \multicolumn{13}{|c|}{ Education (ref. secondary education) } \\
\hline Higher & $\begin{array}{c}0.82^{\star \star \star} \\
(0.01)\end{array}$ & $\begin{array}{c}0.56^{\star \star \star \star} \\
(0.00)\end{array}$ & 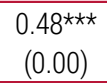 & $\begin{array}{c}0.98 \\
(0.88)\end{array}$ & $\begin{array}{c}0.69 * \star \star \\
(0.00)\end{array}$ & $\begin{array}{c}0.74 \text { }(0.00) \\
(0.00\end{array}$ & $\begin{array}{c}0.64^{\star \star \star} \\
(0.00)\end{array}$ & $\begin{array}{c}0.45^{\star \star \star} \\
(0.00)\end{array}$ & 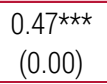 & $\begin{array}{c}0.72^{\star \star \star} \\
(0.00)\end{array}$ & $\begin{array}{c}0.91 \\
(0.29)\end{array}$ & $\begin{array}{c}0.84^{\star \star \star} \\
(0.00)\end{array}$ \\
\hline Primary & $\begin{array}{l}1.85^{\star \star \star} \\
(0.00)\end{array}$ & $\begin{array}{l}1.81^{\star \star \star} \\
(0.00)\end{array}$ & $\begin{array}{c}2.83 * \star \star \\
(0.00)\end{array}$ & $\begin{array}{l}1.32^{\star \star \star} \\
(0.00)\end{array}$ & $\begin{array}{c}1.57^{\star \star \star \star} \\
(0.00)\end{array}$ & $\begin{array}{l}1.52^{\star \star \star \star} \\
(0.00)\end{array}$ & $\begin{array}{c}1.25^{\star \star \star} \\
(0.01)\end{array}$ & $\begin{array}{l}1.94^{\star \star \star} \\
(0.00)\end{array}$ & $\begin{array}{l}1.78 \star \star \star \\
(0.00)\end{array}$ & $\begin{array}{c}1.47^{\star \star \star \star} \\
(0.00)\end{array}$ & $\begin{array}{l}1.62^{\star \star \star} \\
(0.00)\end{array}$ & $\begin{array}{c}1.52^{\star \star \star} \\
(0.00)\end{array}$ \\
\hline \multicolumn{13}{|c|}{ Regional controls } \\
\hline Bartik shock & $\begin{array}{c}1.24^{\star \star \star} \\
(0.00)\end{array}$ & $\begin{array}{l}1.09^{\star \star} \\
(0.03)\end{array}$ & $\begin{array}{c}0.69 \star \star \star \\
(0.00)\end{array}$ & $\begin{array}{c}0.95 \\
(0.27)\end{array}$ & $\begin{array}{c}0.99 \\
(0.65)\end{array}$ & $\begin{array}{c}1.01 \\
(0.23)\end{array}$ & $\begin{array}{c}0.98^{\star \star \star} \\
(0.00)\end{array}$ & $\begin{array}{c}0.92^{\star \star \star} \\
(0.00)\end{array}$ & 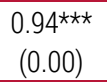 & 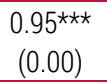 & $\begin{array}{l}1.15^{\star \star \star} \\
(0.00)\end{array}$ & $\begin{array}{c}0.85^{\star \star \star} \\
(0.00)\end{array}$ \\
\hline $\begin{array}{c}\text { Industry } \\
\text { share at the } \\
\text { age of } 15-19\end{array}$ & $\begin{array}{c}0.91^{\star \star \star} \\
(0.00)\end{array}$ & $\begin{array}{c}0.95^{\star \star \star} \\
(0.00)\end{array}$ & $\begin{array}{c}1.02^{\star \star \star} \\
(0.00)\end{array}$ & $\begin{array}{c}0.98^{\star \star \star} \\
(0.00)\end{array}$ & $\begin{array}{c}0.97 \\
(0.45)\end{array}$ & $\begin{array}{c}0.97 \star \star \star \\
(0.00)\end{array}$ & $\begin{array}{c}1.02^{\star \star \star} \\
(0.01)\end{array}$ & $\begin{array}{c}0.99 \star \star \star \\
(0.00)\end{array}$ & $\begin{array}{c}1.00^{\star \star \star \star} \\
(0.00)\end{array}$ & $\begin{array}{c}0.97 \star \star \star \\
(0.00)\end{array}$ & $\begin{array}{c}1.00 \\
(0.91)\end{array}$ & $\begin{array}{c}0.99 * \star \star \\
(0.00)\end{array}$ \\
\hline Constant & $\begin{array}{c}0.17^{\star \star \star} \\
(0.00)\end{array}$ & $\begin{array}{c}0.18^{\star \star \star} \\
(0.00)\end{array}$ & $\begin{array}{c}0.02^{\star \star \star} \\
(0.00)\end{array}$ & $\begin{array}{c}0.06^{\star \star \star} \\
(0.00)\end{array}$ & $\begin{array}{c}0.23 \\
(0.17)\end{array}$ & $\begin{array}{c}0.12^{\star \star \star} \\
(0.00)\end{array}$ & $\begin{array}{c}0.09 \star \star \star \\
(0.00)\end{array}$ & $\begin{array}{c}0.11^{\star \star \star} \\
(0.00)\end{array}$ & $\begin{array}{c}0.12^{\star \star \star} \\
(0.00)\end{array}$ & $\begin{array}{c}0.43^{\star \star \star} \\
(0.00)\end{array}$ & $\begin{array}{c}0.07^{\star \star \star \star} \\
(0.00)\end{array}$ & $\begin{array}{c}0.05^{\star \star \star} \\
(0.00)\end{array}$ \\
\hline Observations & 303,48 & 155,52 & 128,7 & 174,73 & 47,47 & 946,37 & 147,74 & 352,54 & 554,36 & 282,87 & 621,65 & 247,8 \\
\hline
\end{tabular}

Note: Due to data availability, 1999-2001 for Germany and the United Kingdom, 2003-2005 for Sweden. The standard errors are clustered at the occupation level. P-value in parentheses. ${ }^{* * *} p<0.01, * * p<0.05, * p<0.1$.

Source: Own estimations based on EU-LFS, O*NET, and Cambridge Econometrics European Regional Data. 
Figure A1. Average RTI values in Western European countries and in Central and Eastern European (CEE) countries between 1998 and 2010.

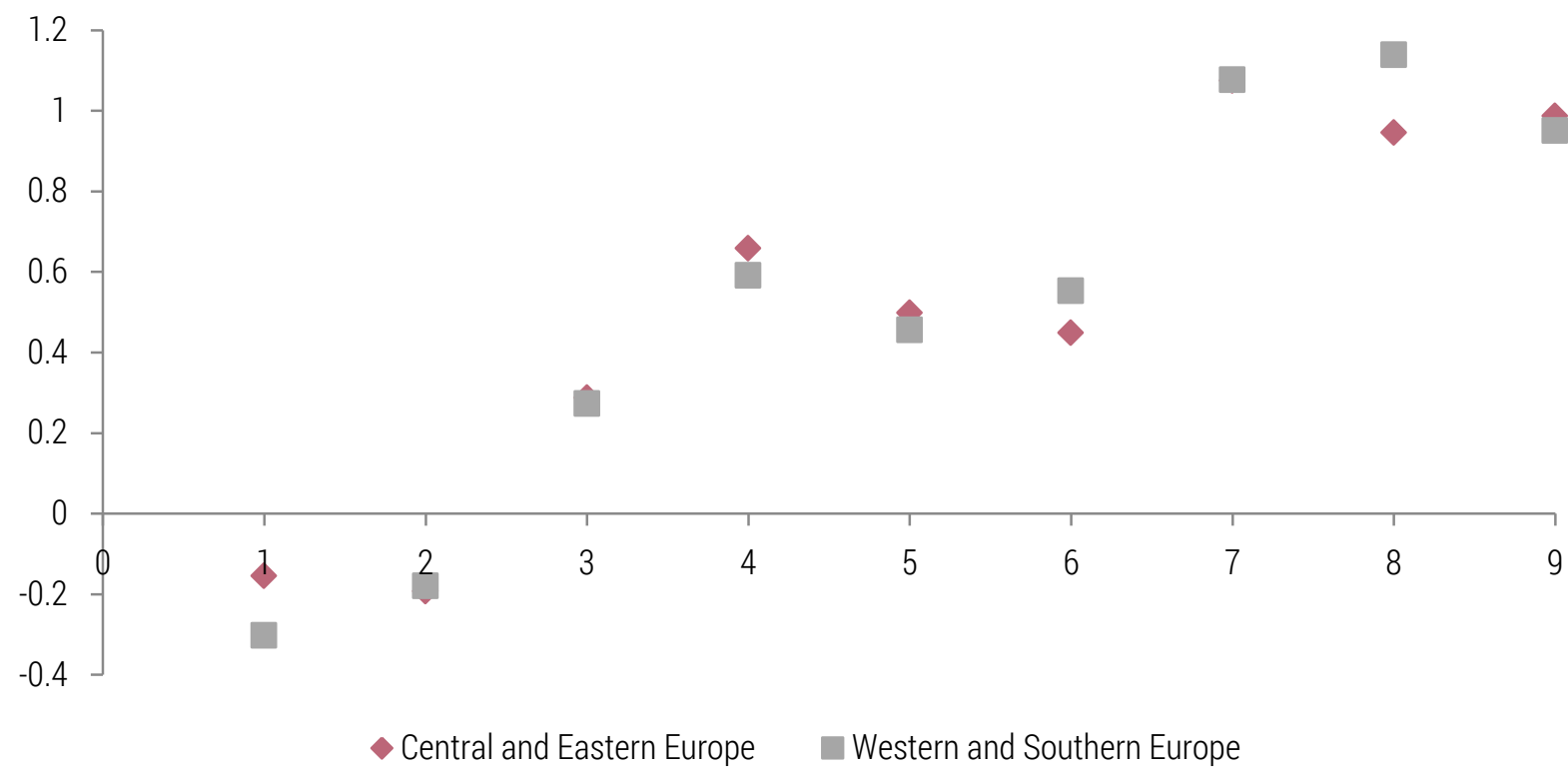

Source: Own calculations based on EU-LFS and O*NET data.

Figure A2. Linear time-trend coefficients from unweighted regressions estimated for the tasks intensities in the 19982015 period across age groups.
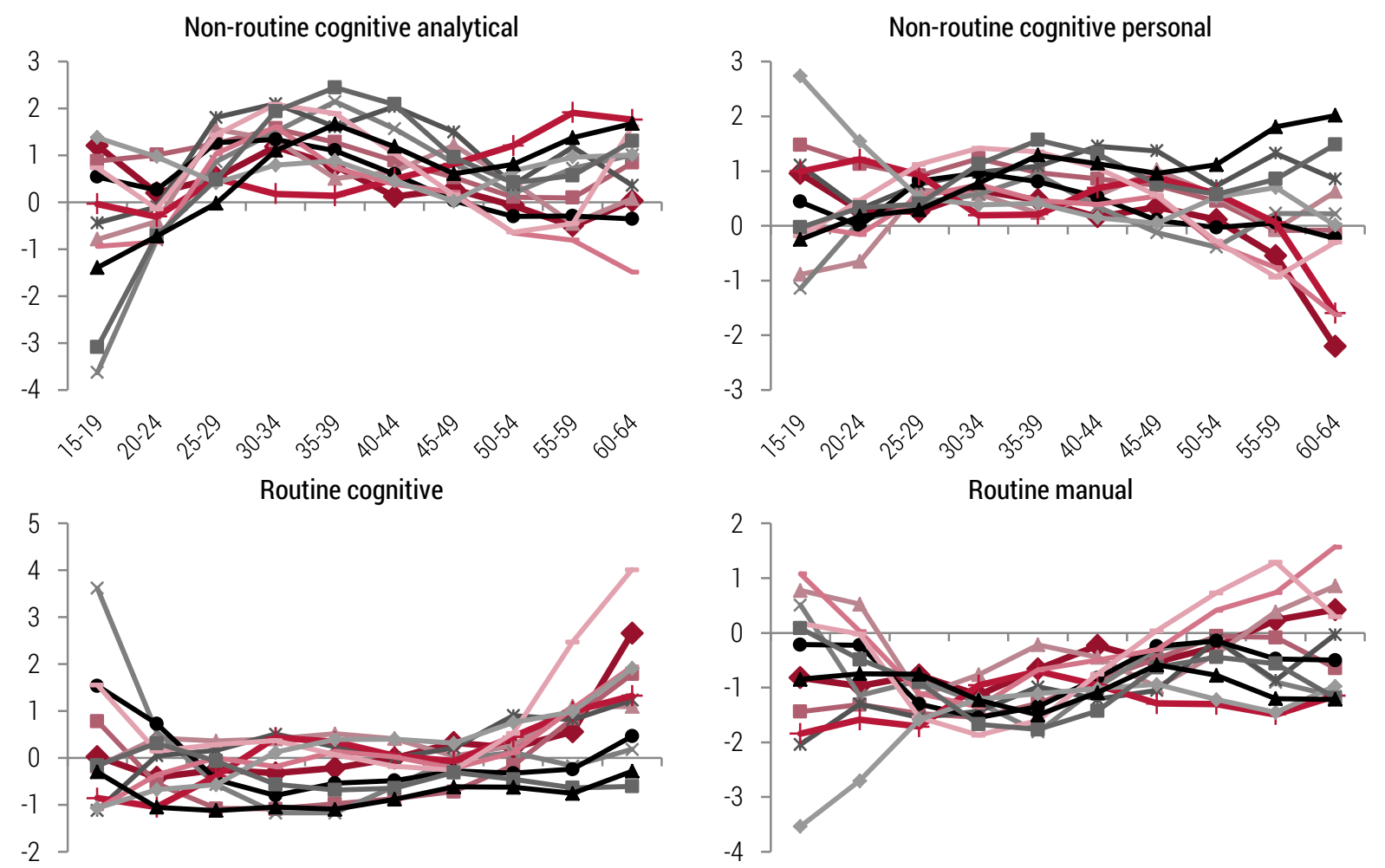

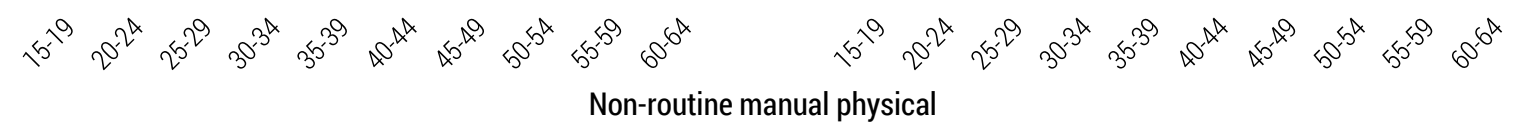




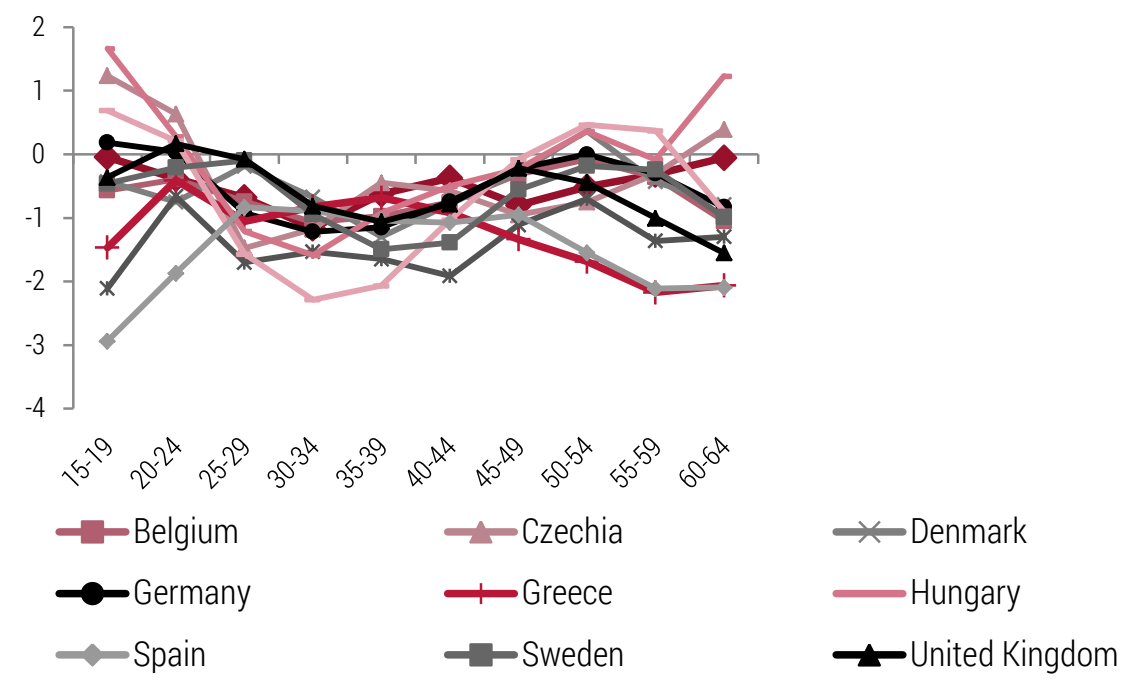

Note: Each coefficient estimated in a separate country-specific regression with a particular task content intensity in a given age group as the explained variable and time-trend as the control variable.

Source: Own estimations based on EU-LFS \& O*NET data. 


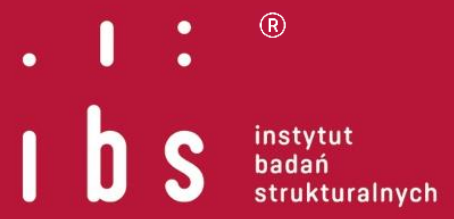

www.ibs.org.pl 